\title{
Divergent $\mathrm{T}-\mathrm{fO}_{2}$ paths during crystallisation of $\mathrm{H}_{2} \mathrm{O}$-rich and $\mathrm{H}_{2} \mathrm{O}$ - poor magmas as recorded by $\mathrm{Ce}$ and $\mathrm{U}$ in zircon, with implications for TitaniQ and TitaniZ geothermometry
}

\author{
Robert R. Loucks ${ }^{1,2}$ (D) Marco L. Fiorentini ${ }^{1,2} \cdot$ Bruce D. Rohrlach $^{3,4}$
}

Received: 4 April 2018 / Accepted: 9 November 2018 / Published online: 23 November 2018

(C) The Author(s) 2018

\begin{abstract}
During solidification of magma chambers as systems closed to chemical exchange with environs, the residual siliceous melt may follow a trend of rising, constant, or decreasing oxidation state, relative to reference buffers such as nickel + nickel oxide (NNO) or fayalite + magnetite + quartz. Titanomagnetite-hemoilmenite thermometry and oxybarometry on quenched volcanic suites yield temperature versus oxygen fugacity arrays of varied positive and negative slopes, the validity of which has been disputed for several years. We resolve the controversy by introducing a new recorder of magmatic redox evolution employing temperature- and redox-sensitive trace-element abundances in zircon. The zircon/melt partition coefficients of cerium and uranium vary oppositely in response to variation of magma redox state, but vary in tandem as temperature varies. Plots of U/Pr versus $\mathrm{Ce}^{4+} /$ $\mathrm{Ce}^{3+}$ in zircon provide a robust test for change in oxidation state of the melt during zircon crystallisation from cooling magma, and the plots discriminate thermally induced from redox-induced variation of $\mathrm{Ce}^{4+} / \mathrm{Ce}^{3+}$ in zircon. Temperature-dependent lattice strain causes $\mathrm{Ce}^{4+} / \mathrm{Ce}^{3+}$ in zircon to increase strongly as zircon crystallises from cooling magma at constant $\mathrm{Ce}^{4+} / \mathrm{Ce}^{3+}$ ratio in the melt. We examine 19 zircon populations from igneous complexes in varied tectonic settings. Variation of zircon $\mathrm{Ce}^{4+} / \mathrm{Ce}^{3+}$ due to minor variation in melt oxidation state during crystallisation is resolvable in 11 cases but very subordinate to temperature dependence. In many zircon populations described in published literature, there is no resolvable change in redox state of the melt during tenfold variation of $\mathrm{Ce}^{4+} / \mathrm{Ce}^{3+}$ in zircons. Varied magmatic redox trends indicated by different slopes on plots of zircon $\mathrm{U} / \mathrm{Pr}$ versus $\mathrm{Ce}^{4+} / \mathrm{Ce}^{3+}$ are corroborated by $\mathrm{Fe}$-Ti-oxide-based $\mathrm{T}-\mathrm{fO}_{2}$ trends of correspondingly varied slopes. Zircon and Fe-Ti-oxide compositions agree that exceptionally, $\mathrm{H}_{2} \mathrm{O}$-rich arc magmas tend to follow a trend of rising oxidation state of the melt during late stages of fluid-saturated magmatic differentiation at upper-crustal pressures. We suggest that $\mathrm{H}_{2}$ and/or $\mathrm{SO}_{3}$ and/or $\mathrm{Fe}^{2+}$ loss from the melt to segregating fluid is largely responsible. Conversely, zircon and Fe-Ti-oxide compositions agree in indicating that $\mathrm{H}_{2} \mathrm{O}$-poor magmas tend to follow a $\mathrm{T}-\mathrm{fO}_{2}$ trend of decreasing oxidation state of the melt during late stages of magmatic differentiation at upper-crustal pressures, because the precipitating mineral assemblage has higher $\mathrm{Fe}^{3+} / \mathrm{Fe}^{2+}$ than coexisting rhyolitic melt. We present new evidence showing that the Fe-Ti-oxide oxybarometer calibration by Ghiorso and Evans (Am J Sci 308(9):957-1039, 2008) retrieves experimentally imposed values of $\mathrm{fO}_{2}$ in laboratory syntheses of Fe-Ti-oxide pairs to a precision of $\pm 0.2 \mathrm{log}$ unit, over a large experimental temperature range, without systematic bias up to at least $\log \mathrm{fO}_{2} \approx \mathrm{NNO}+4.4$. Their titanomagnetite-hemoilmenite geothermometer calibration has large systematic errors in application to Ti-poor oxides that precipitate from very oxidised magmas. A key outcome is validation of Fe-Ti-oxide-based values of melt $\mathrm{TiO}_{2}$ activity for use in Ti-in-zircon thermometry and Ti-in-quartz thermobarometry.
\end{abstract}

Keywords Magmatic oxidation state $\cdot \mathrm{Ce}^{4+} / \mathrm{Ce}^{3+}$ in zircon $\cdot$ Fe-Ti-oxide geothermometry $\cdot$ Fe-Ti-oxide oxybarometry . Ti-in-zircon geothermometer $\cdot$ Ti-in-quartz geothermometer

Communicated by Timothy L. Grove.

Electronic supplementary material The online version of this article (doi:https://doi.org/10.1007/s00410-018-1529-3) contains supplementary material, which is available to authorized users.

Extended author information available on the last page of the article

\section{Introduction}

Accurate geothermometry is a key that often unlocks access to other geologically useful information from chemically analysed glass and/or mineral assemblages-e.g., rock or magma viscosity, pressure of crystallisation and depth of 
subsequent erosional exhumation, oxygen or sulphur fugacity, or the dissolved $\mathrm{H}_{2} \mathrm{O}$ content in a magma. These pieces of information may be required by earth scientists investigating problems as diverse as rock mechanics, crustal deformation dynamics, ore-forming processes, and volcanic eruption dynamics. Reliable characterisation of the redox state of magmas is important, because about $20 \%$ of the elements in the periodic table vary in ionic charge within the range of oxidation states of terrestrial and lunar silicate melts. In many cases, whether an element is sequestered in early minerals or accumulates in residual melts depends on the oxidation state of the melt, which enhances or thwarts a magma's ability to produce ore deposits of many elements. The oxidation state of sulphur in silicate melts strongly influences its availability for degassing during volcanic eruptions, with climatic implications (Scaillet et al. 1998; Burgisser and Scaillet 2007). Evolution of the oxidation state of silicate melts during generation and crystallisation is normally dominated by the $\mathrm{Fe}^{3+} / \mathrm{Fe}^{2+}$ couple, with the $\mathrm{S}^{6+} / \mathrm{S}^{2-}$ couple usually playing a subordinate but occasionally dominant role (Carmichael and Ghiorso 1986), whereas the other redoxsensitive elements are present in natural silicate magmas in relatively low concentrations and respond passively but promptly to the lead by iron and sulphur.

The widely used Ti-in-zircon geothermometer and Ti-inquartz geothermobarometer are sensitive to errors in estimates of melt $\mathrm{TiO}_{2}$ activity, which are required as input data (Yakymchuk et al. 2017). Different methods of evaluating $a_{\mathrm{TiO}} \mathrm{mel}_{2}$ give substantially discrepant results. As an example, for the Bishop Tuff melt $a_{\mathrm{TiO}_{2}}^{\text {melt }}$ has been estimated at 0.45-0.65 using the Fe-Ti-oxide method (Ghiorso and Gualda 2013), but Thomas and Watson (2012) obtained $a_{\mathrm{TiO}_{2}}^{\mathrm{melt}}=0.15$ using the Rhyolite-MELTS algorithm of Gualda et al. (2012). At an actual crystallisation temperature of, say, $750{ }^{\circ} \mathrm{C}$, these discrepancies in $a_{\mathrm{TiO}_{2}}^{\text {melt }}$ correspond to temperature discrepancies of $\sim 60$ to $100{ }^{\circ} \mathrm{C}$, and many kilobars discrepancy in pressures calculated by the Ti-in-quartz geobarometer (Kularatne and Audétat 2014). Kularatne and Audétat report experimentally based values of $a_{\mathrm{TiO}_{2}}^{\mathrm{melt}}$ in the Bandelier Tuff, Oruanui Tuff, Fish Canyon Tuff, and Bishop Tuff which are consistently $\sim 50$ to $200 \%$ larger than thermodynamic estimates by RhyoliteMELTS for the same analysed glass samples.

Disagreement about evaluation of $a_{\mathrm{TiO}_{2}}^{\text {melt }}$ may underlie a dispute in the literature (e.g., Ghiorso and Gualda 2013; Ghiorso et al. 2016; Gualda et al. 2017; Evans and Bachmann 2013; Chamberlain et al. 2015; Evans et al. 2016) as to whether the reducing-cooling trend in the Bishop Tuff (Fig. 1) and similar T- $\Delta_{\mathrm{NNO}} f \mathrm{O}_{2}$ trends of Yellowstone caldera tuffs, Cougar Point Tuff, Mt. Katmai, and Toba Tuff are a valid representation of $\mathrm{T}-\mathrm{fO} \mathrm{O}_{2}$ conditions in the melt in their pre-eruption magma chambers.

In this paper, we proceed by examining the reliability of the Fe-Ti-oxide geothermometer-oxybarometer calibration that is the basis of the contentious T- $\Delta$ NNO trends, as plotted in Fig. 1. This is followed by introduction of zircon traceelement indicators of temperature variation and redox variation in magmas during crystallisation of zircon populations from many volcanic and intrusive complexes. Some of the zircon populations are from volcanic suites in which $\mathrm{Fe}-\mathrm{Ti}$ oxides have also been analysed, providing a test for consistency of results. These tests are followed by interpretation of the causes of variation among temperature-redox trends during crystallisation-differentiation of varied magma types, and by suggestions for improved thermodynamic modelling of $\mathrm{TiO}_{2}$ activity in silicate melts.

\section{Conflicting opinions on validity of varied Fe- Ti-oxide-based $\mathrm{T}-\mathrm{fO}_{2}$ trends}

Titanomagnetite-hemoilmenite geothermometry and oxybarometry, as thermodynamically calibrated by Anderson et al. (1993) and by Ghiorso and Evans (2008), are widely applied to volcanic rocks with the aim of recovering information about intra-telluric conditions preceding eruption. The validity of the variation among $\mathrm{T}-\mathrm{fO}_{2}$ trends obtained from $\mathrm{Fe}-\mathrm{Ti}$ oxides in Fig. 1 has been questioned by Ghiorso and Gualda (2013), who note that trends having positive slopes are inconsistent with predictions by the MELTS and Rhyolite-MELTS free-energy-minimisation algorithms (Gualda et al. 2012; Ghiorso and Gualda 2013). Rhyolite-MELTS modelling of Bishop Tuff compositions has been used to propose that the crystallisation temperature for Bishop Tuff phenocrysts lies within a $10{ }^{\circ} \mathrm{C}$ range from top to bottom of the eruptive sequence (Gualda et al. 2012, 2017), whereas Bindeman and Valley (2002), Hildreth and Wilson (2007), Evans and Bachmann (2013), Chamberlain et al. (2015), and Evans et al. (2016) present mutually consistent results from zircon-saturation thermometry, two-feldspar thermometry, Ti-in-quartz thermometry, $\delta^{18} \mathrm{O}_{\text {magnetite-quartz }}$ thermometry and $\mathrm{Fe}$-Ti-oxide thermometry documenting a vertical gradient of $\sim 100{ }^{\circ} \mathrm{C}$ in the pre-eruptive Bishop Tuff magma chamber tapped by the eruptive sequence. Bindeman and Valley (2002) also report a vertical gradient of $\sim 112{ }^{\circ} \mathrm{C}$ indicated by $\delta^{18} \mathrm{O}_{\text {magnetite-quartz }}$ thermometry in pre-eruptive magma chamber of the Lava Creek Tuff (Yellowstone), which corroborates the range, as shown in Fig. 1.

Ghiorso and Evans (2008) and Ghiorso and Gualda (2013) and Gardner et al. (2014) show plots of temperature versus oxygen fugacity in the Bishop Tuff derived by applying the Ghiorso and Evans (2008) calibration of the $\mathrm{Fe}$-Ti-oxide oxybarometer-thermometer to compositions of 
Fig. 1 Divergent trends of magmatic temperature and oxidation state relative to the nickel metal + nickel-oxide reference buffer, $\triangle \mathrm{NNO}$, during late, felsic stages of magma evolution, as recorded by titanomagnetite-hemoilmenite phenocryst pairs in volcanic suites and evaluated by the Ghiorso and Evans (2008) calibration of the Fe-Ti-oxide oxybarometerthermometer. They are shown in two panels to avoid obfuscating overlap. These trends are to be compared with redox trends recorded by analyses of zircon populations which are available for Bishop, Yellowstone, St Helens Yn, South Sister, Toba, and Tampakan. Fe-Ti oxide compositions in the White River Ash are from Preece et al. (2014); Mt St Helens Yn tephra, Gardner et al. (1995); Mt St Helens May 1980 and Shiveluch from Blundy et al. (2006, 2008); South Sister Devil's Hills rhyolitic domes, Stelten and Cooper (2012); Cougar Point Tuff, Cathey and Nash (2004); Toba Tuff, Chesner (1998). Data for Daisen, Fish Canyon Tuff, Katmai, Bishop Tuff, and Yellowstone Lake Creek and Huckleberry Ridge tuffs are from the compilation by Ghiorso and Evans (2008), which cites literature sources. The NNO and FMQ buffer curves are from Pownceby et al. (1994) and from O’Neill (1987), respectively
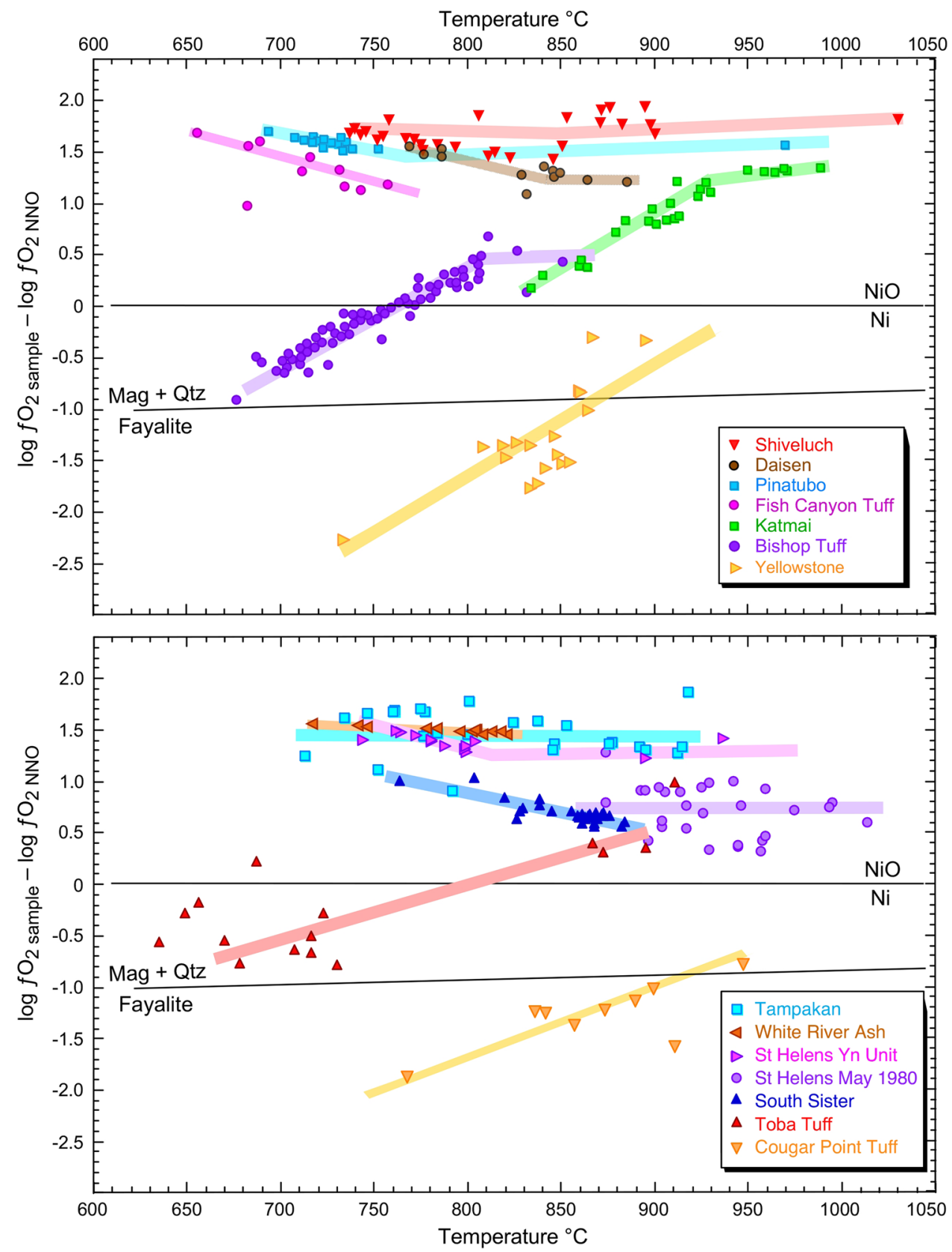

Titanomagnetite-hemoilmenite phenocryst pairs reported by Hildreth and Wilson (2007), as shown in Fig. 1. Ghiorso and Gualda (2013) suggest that the discrepancy between the Rhyolite-MELTS model and the Fe-Ti-oxide-based T- $\mathrm{fO}_{2}$ in the Bishop Tuff eruptive suite implies that the $\mathrm{Fe}-\mathrm{Ti}$ oxide phenocrysts (or ilmenite, in particular) were not in equilibrium with the melt that is represented by enclosing volcanic glass. Ghiorso and Gualda (2013) contend that, in that case, the crystal-melt disequilibrium would propagate to erroneous estimates of the thermodynamic activity of $\mathrm{TiO}_{2}$ in the melt, which would propagate, in turn, to erroneous estimates of magma temperature based on Ti-in-zircon (TitaniZ) geothermometry (Ferry and Watson 2007) and
Ti-in-quartz (TitaniQ) geothermobarometry (Wark and Watson 2006; Huang and Audétat 2012; Kularatne and Audétat 2014), both of which require input of $\mathrm{TiO}_{2}$ activity for temperature calculations.

In contrast, Evans and Bachmann (2013) present several lines of evidence that eruption of the Bishop Tuff magma preserved equilibrium of exchange components and element concentrations among magnetite, ilmenite, biotite, apatite, zircon, and liquid. Evans et al. (2016) and earlier papers cited therein offer numerous lines of independent thermometric and other evidence that the Fe-Ti-oxide phenocrysts probably also maintained equilibrium with feldspars and quartz in the Bishop Tuff magma. Evans et al. (2016) 
contend that the $\mathrm{T}-\mathrm{fO}_{2}$ trend recovered from the analytical data of Hildreth and Wilson (2007) and thermodynamic calibration by Ghiorso and Evans (2008) are a valid representation of the $\mathrm{T}-\mathrm{fO}_{2}$ conditions in the zoned Bishop Tuff magma chamber. In that case, questions arise regarding the adequacy of the calibration data or thermodynamic procedures used by the Rhyolite-MELTS free-energy-minimization algorithm (Gualda et al. 2012; Ghiorso and Gualda 2013) for calculating $a_{\mathrm{TiO}_{2}}^{\mathrm{melt}}$, with implications for its reliabil-

ity in thermodynamic modelling of silicic melts more generally.

Trail et al. (2015) present a $\mathrm{T}-\mathrm{fO}_{2}$ trend for the Bishop Tuff magma, based on X-ray absorption near-edge structure (XANES) measurements of the $\mathrm{Ce}^{4+} / \mathrm{Ce}^{3+}$ ratio in zoned zircons and Ti-in-zircon geothermometry in one pumice sample, showing a rise in $\mathrm{Ce}^{4+} / \mathrm{Ce}^{3+}$ ratio toward the lower temperature rims of the zircon crystals. They interpret their rim-ward rise of $\mathrm{Ce}^{4+} / \mathrm{Ce}^{3+}$ as supporting the arguments by Ghiorso and Gualda (2013) that the cooling-reducing T- $\mathrm{fO}_{2}$ trend indicated by $\mathrm{Fe}-\mathrm{Ti}$ oxides in the Bishop Tuff is not valid. In that case, cooling-reducing trends indicated by $\mathrm{Fe}-\mathrm{Ti}$ oxides in rhyolites at other eruptive centres (Fig. 1), such as Yellowstone caldera tuffs, Cougar Point Tuff, Katmai/Novarupta tuff, and the Toba Tuff are dubious too, as they also violate melt evolution trends derived by the Rhyolite-MELTS algorithm (Ghiorso and Gualda 2013).

\section{Test of the Ghiorso and Evans (2008) Fe- Ti-oxide thermometer-oxybarometer}

To resolve these conflicting propositions, we begin by testing the reliability of the Ghiorso and Evans (2008) thermodynamic calibration of the $\mathrm{Fe}$-Ti-oxide oxybarometer by using it to calculate $\mathrm{fO}_{2}$ values from titanomagnetite-hemoilmenite compositions synthesised at controlled $\mathrm{fO}_{2}$ and temperature in seven experimental studies (listed in Electronic Supplementary Material 1). Most of them are represented in a plot of $\Delta \mathrm{NNO}$ vs T shown as Fig. 27 of Ghiorso and Evans (2008), but we use here different plotting variables, and we include some additional experimental data (Blatter et al. 2013) that were not included in their calibration dataset.

Excluding only the highly deviant results of the study by Prouteau and Scaillet (2003) at $9.2 \mathrm{kbar}$ in extremely hydrous felsic melts, we show in Fig. 2a that the Ghiorso and Evans (2008) oxybarometer retrieves the reported experimental $\mathrm{fO}_{2}$ values of all 45 experiments in the other seven studies with a standard error of just $\pm 0.2 \log$ unit $\mathrm{fO}_{2}$, which does not exceed the 0.2-0.3 log unit uncertainty in experimental control of $\mathrm{fO}_{2}$ (Scaillet and Evans 1999; Pichavant et al. 2002). Figure $2 b$ shows large deviations of calculated temperatures from the reported experimental temperatures

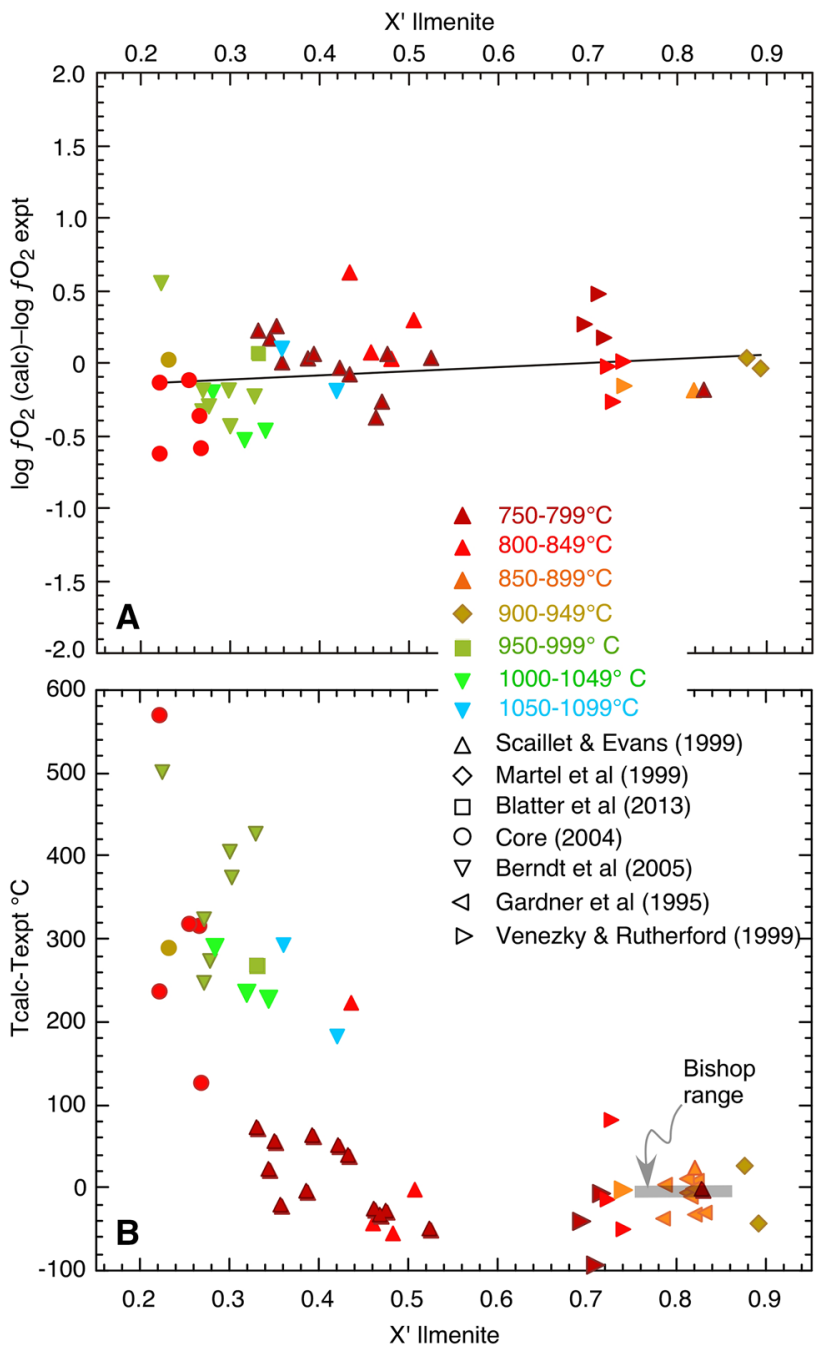

Fig. 2 a Reliability of the Ghiorso and Evans (2008) thermodynamic calibration of the Fe-Ti-oxide oxybarometer is tested by using it to calculate $\mathrm{fO}_{2}$ values (at experiment temperatures) from titanomagnetite-hemoilmenite compositions reported in 45 experiments by seven investigative groups over an experimentally controlled (buffered) $\log \mathrm{fO}_{2}$ range from $\mathrm{NNO}$ to $\mathrm{NNO}+4.4,0.5$ to $7 \mathrm{kbar}$ (mostly 2-3 kbar), and $750-1050{ }^{\circ} \mathrm{C}$ in hydrous, metaluminous bulk compositions. Colours represent experimental temperature intervals; symbols of different shape identify different investigations. The abscissa variable is the mole fraction of $\mathrm{FeTiO}_{3}$ in $\mathrm{Mg}-\mathrm{Fe}-\mathrm{Mn}-\mathrm{Al}-\mathrm{Ti}$ hemoilmenite projected onto the $\mathrm{FeTiO}_{3}-\mathrm{Fe}_{2} \mathrm{O}_{3}$ binary, calculated according to the procedure of Ghiorso and Evans (2008). b There are large systematic deviations of temperatures calculated by the Ghiorso and Evans (2008) geothermometer from Fe-Ti-oxide pairs synthesised at high $\mathrm{fO}_{2}$ (low mole fraction $\mathrm{FeTiO}_{3}$ ), evident in this plot of the same experiments as in a. But over the composition range of $\mathrm{Fe}$-Ti-oxide pairs in the Bishop Tuff (grey bar; Hildreth 1977; Hildreth and Wilson 2007), the geothermometer is accurate. The plotted data are listed in the Electronic Supplementary Material 1

for Ti-poor oxide pairs synthesised at high $\mathrm{fO}_{2}$. Under those conditions, experimental calibration data available to Ghiorso and Evans were scant; in a Roozeboom plot of $X_{\text {ilm }}$ versus $X_{\text {ulv }}$ (Ghiorso and Evans 2008, their Fig. 14), 
isotherms converge tightly, causing poor temperature resolution in Ti-poor compositions. The data trend at low $X_{\text {ilmenite }}$ in Fig. 2b may be used to estimate empirical corrections to calculated temperatures of Ti-poor oxide pairs until an improved thermodynamic model becomes available. However, Fig. $2 \mathrm{~b}$ also indicates that the Ghiorso and Evans (2008) Fe-Ti-oxide geothermometer is accurate in the composition range of $\mathrm{Fe}-\mathrm{Ti}$ oxides in the Bishop Tuff and other suites plotted in Fig. 1 ( $X_{\text {ilmenite }}>0.45, \Delta \mathrm{NNO} \leq 2$ ). Therefore, we conclude that mis-calibration of the titanomagnetite-hemoilmenite oxybarometer-thermometer is not responsible for the disagreement of the positive $\mathrm{T}-\mathrm{fO}_{2}$ trend of the Bishop Tuff Fe-Ti-oxide data in Fig. 1 with the negative slope of the magmatic $\mathrm{T}-\mathrm{fO}_{2}$ trend predicted by Rhyolite-MELTS or negative T- $\mathrm{fO}_{2}$ slope inferred by Trail et al. (2015) from zircon $\mathrm{Ce}^{4+} / \mathrm{Ce}^{3+}$ measurements and Tiin-zircon temperatures.

\section{Independent test of magmatic $\mathrm{T}-\mathrm{fO}_{2}$ trends using $\mathrm{Ce}$ and $\mathrm{U}$ redox couples}

Zircon takes in cerium and uranium in quantities that are easy to measure quantitatively. Zircon is very resistant to adjustment of its initial composition by ion diffusion within the crystal lattice (Cherniak and Watson 2003). Ce and U vary in ionic charge within the $\mathrm{fO}_{2}$ range of terrestrial silicate melts; zircon/melt partition coefficients of $\mathrm{Ce}$ and $\mathrm{U}$ vary sensitively with $\mathrm{fO}_{2}$ and can, in principle, be used as magmatic oxybarometers. We examine first the variation in ionic charge of $\mathrm{Ce}$ and $\mathrm{U}$ in the melt as its $\mathrm{T}$ and $\mathrm{fO}_{2}$ vary and follow with an examination of the role of temperaturesensitive lattice strain on zircon/melt partition coefficients of $\mathrm{U}^{4+}, \mathrm{U}^{5+}, \mathrm{Ce}^{4+}, \mathrm{Ce}^{3+}$, and trivalent lanthanides. That is followed by introduction of plots of $\mathrm{U} / \mathrm{Pr}$ versus $\mathrm{Ce}^{4+} / \mathrm{Ce}^{3+}$ in zircon as robust indicators of $\mathrm{T}-\mathrm{fO}_{2}$ trends as zircon crystallises during magmatic differentiation. Those zircon-based magmatic redox trends are to be compared with Fe-Ti-oxide trends in Fig. 1 to test for consistency.

\section{Relative sensitivity of $\mathrm{Ce}, \mathrm{U}$, and Fe redox couples in the melt to variation of $\mathrm{T}$ and $\mathrm{fO}_{2}$}

The effect of varying temperature on $\mathrm{Ce}^{4+} / \mathrm{Ce}^{3+}$ and $\mathrm{U}^{5+} /$ $\mathrm{U}^{4+}$ in silicate melts is illustrated in Fig. 3. These show that the $\mathrm{T}-\mathrm{fO}_{2}$ slopes of contours of $\mathrm{Ce}^{4+} / \mathrm{Ce}^{3+}$ and $\mathrm{U}^{5+} / \mathrm{U}^{4+}$ in the melt are nearly indistinguishable from the slope of $\mathrm{Fe}^{3+}$ / $\mathrm{Fe}^{2+}$ contours in the melt and from the NNO and FMQ reference buffers. Schreiber (1987) and Schreiber et al. (1987) use redox micro-titrations and optical spectroscopy to measure redox ratios in silicate glasses quenched at varied $\mathrm{fO}_{2}$. They report $\mathrm{Ce}^{4+} / \mathrm{Ce}^{3+}=1$ at $\log \mathrm{fO}_{2}=-0.25$ at $1150{ }^{\circ} \mathrm{C}$ and at $\log \mathrm{fO}_{2}=+3.13$ at $1500{ }^{\circ} \mathrm{C}$ (uncertainties are not

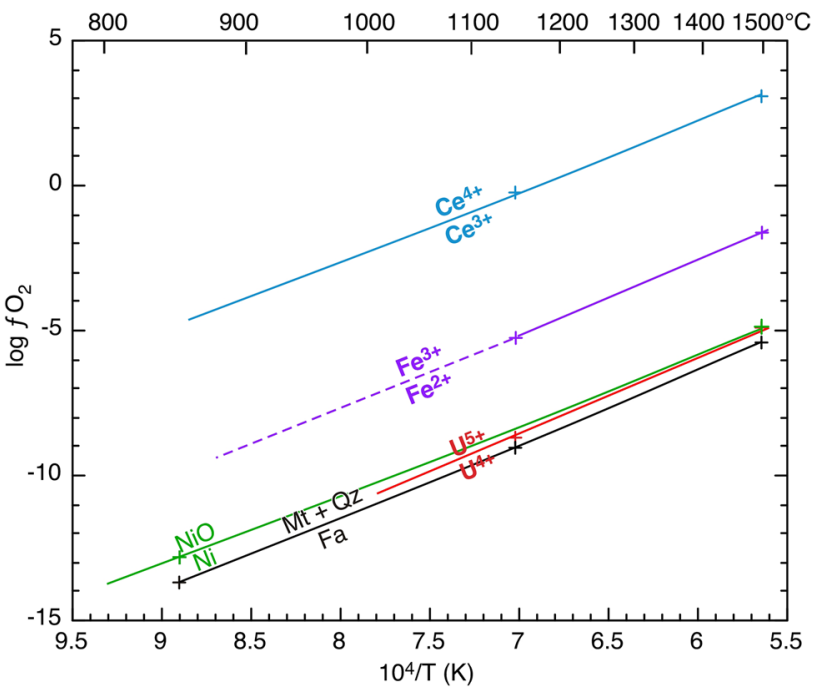

Fig. 3 Position and slope of the fayalite-magnetite-quartz equilibrium and nickel metal-nickel oxide equilibrium, as calibrated by O'Neill (1987) and Pownceby and O'Neill (1994), are compared with experimentally calibrated contours along which $\mathrm{Ce}^{4+} / \mathrm{Ce}^{3+}$ and $\mathrm{U}^{5+}$ $\mathrm{U}^{4+}$ and $\mathrm{Fe}^{3+} / \mathrm{Fe}^{2+}$ in the silicate melt are unity. The cerium and uranium redox ratios in synthetic aluminosilicate glasses at 1150 and $1500{ }^{\circ} \mathrm{C}$ are from Schreiber (1987) and Schreiber et al. (1987). The curve for $\mathrm{Fe}^{3+} / \mathrm{Fe}^{2+}$ is according to the experimental calibration by Kress and Carmichael (1991). Near parallelism of the curves implies very similar enthalpies for these redox reactions

given). They report that $\mathrm{U}^{5+} / \mathrm{U}^{4+}=1$ at $\log \mathrm{fO}_{2}=-8.8$ at $1150{ }^{\circ} \mathrm{C}$ and $\log f \mathrm{O}_{2}=-5.1$ at $1500{ }^{\circ} \mathrm{C}$. Those results are in satisfactory accord with $\mathrm{fO}_{2}$ dependence of mineral/melt partition coefficients of $\mathrm{Ce}$ and $\mathrm{U}$, as experimentally constrained by Burnham and Berry (2012) and of U by Fonseca et al. (2014), and in accord with range brackets by Farges et al. (1992) on $\mathrm{U}^{5+} / \mathrm{U}^{4+}$ measured by optical spectroscopy in aluminosilicate glasses synthesised at varied $\mathrm{fO}_{2}$.

We can calculate the average enthalpy of the $\mathrm{Ce}$ and $\mathrm{U}$ redox reactions in the melt over that temperature interval using the Van't Hoff relation ( $T$ in kelvins):

$\log f \mathrm{O}_{2(T 2)}-\log f \mathrm{O}_{2(T 1)}=\frac{H}{2.303 R} \times\left(\frac{1}{T 2}-\frac{1}{T 1}\right)$.

We obtain $\Delta H=-466.55 \mathrm{~kJ}$ for the homogenous reaction $2 \mathrm{Ce}_{2} \mathrm{O}_{3}+\mathrm{O}_{2}=4 \mathrm{CeO}_{2}$ in the melt. That value compares closely with $-463.44 \mathrm{~kJ}$ for the NNO buffer reaction $2 \mathrm{Ni}+\mathrm{O}_{2}=2 \mathrm{NiO}$ (Pownceby and O'Neill (1994). For the uranium oxidation reaction $4 \mathrm{UO}_{2}+\mathrm{O}_{2}=4 \mathrm{UO}_{2.5}$ in the melt, we obtain $\Delta H=-510.72 \mathrm{~kJ}$. That result is close to $\Delta H=-499.18 \mathrm{~kJ}$ for the FMQ buffer reaction, $3 \mathrm{Fe}_{2} \mathrm{SiO}_{4}$ $+\mathrm{O}_{2}=2 \mathrm{Fe}_{3} \mathrm{O}_{4}+3 \mathrm{SiO}_{2}$ in the same temperature interval (O'Neill 1987). Our result for the cerium oxidation reaction is in accord with the value $-436.8 \pm 38.4 \mathrm{~kJ}(2 \sigma)$ reported by Smythe and Brenan (2015) in experiments at $1200-1500{ }^{\circ} \mathrm{C}$ 
and 1 bar $\mathrm{fO}_{2}$ on anhydrous, Fe-free, metaluminous haplobasalt, haplo-andesite, and haplo-rhyolite compositions in which $\mathrm{Ce}^{4+} / \mathrm{Ce}^{3+}$ was determined potentiometrically and by XANES spectroscopy. Our result for Ce is also compatible with a value of $-397 \pm 292 \mathrm{~kJ}(2 \sigma)$ reported by Burnham and Berry (2014) in experiments at $1300-1500{ }^{\circ} \mathrm{C}$ in melt of anorthite-diopside eutectic composition in which they measured $\mathrm{Ce} 4+/ \mathrm{Ce} 3+$ by XANES in the quenched glass. We are unaware of any independent constraints on the enthalpy of the $\mathrm{U}^{4+} \rightarrow \mathrm{U}^{5+}$ reaction.

The results calculated above and shown in Fig. 3 indicate that $\mathrm{T}-\mathrm{fO}_{2}$ slopes of the $\mathrm{Ce}$ and $\mathrm{U}$ redox reactions in aluminosilicate melts are statistically indistinguishable from the $\mathrm{T}-\mathrm{fO}_{2}$ slopes of the NNO and FMQ reference buffers. We expect that magmatic differentiation trends at essentially constant $\mathrm{Ce}^{4+} / \mathrm{Ce}^{3+}$ and $\mathrm{U}^{5+} / \mathrm{U}^{4+}$ in the melt are the usual case over most of the course of magmatic differentiation in upper-crustal magma chambers. Carmichael (1991) reports that experimentally constrained $\mathrm{T}-\mathrm{fO}_{2}$ slopes of contours of $\mathrm{Fe}^{3+} / \mathrm{Fe}^{2+}$ in metaluminous aluminosilicate melts are also indistinguishable from those of the NNO and FMQ buffers, as we illustrate in Fig. 3. As he shows, natural metaluminous magmatic differentiation series that are dominated by fractional crystallisation in convergent and divergent platemargin and intra-plate tectonic settings typically evolve from basaltic-andesitic through dacitic compositions along $\mathrm{T}-\mathrm{fO}_{2}$ trends subparallel to NNO or FMQ:

- Hildreth (1983) uses Fe-Ti oxide phenocryst pairs to document a $\mathrm{T}-\mathrm{fO}_{2}$ trend from andesitic to felsic melts subparallel to the FMQ buffer at Mt. Katmai, Alaska.

- Blundy et al. $(2006,2008)$ demonstrate Fe-Ti-oxidebased $\mathrm{T}-\mathrm{fO}_{2}$ trends parallel to NNO in arc andesite-todacite differentiation series at Shiveluch (Kamchatka) and Mt St Helens (Washington).

- Rohrlach (2002) and Rohrlach and Loucks (2005) show $\mathrm{Fe}-\mathrm{Ti}$-oxide-based $\mathrm{T}-\mathrm{fO}_{2}$ trends parallel to NNO in arc andesite-to-dacite differentiation series at Tampakan volcano (Mindanao, Philippines).

- Perfit and Fornari (1983a, b) report that along the Eastern Galapagos Rift spreading ridge and Inca Transform, the magmatic differentiation series from olivine tholeiitic melts to $\mathrm{Fe}-\mathrm{Ti}$ basalt to icelandite and ferro-dacite (glass compositions 51-64 wt $\% \mathrm{SiO}_{2}$ and 7.5 to $1.0 \mathrm{wt} \% \mathrm{MgO}$ ) evolved subparallel to the FMQ buffer along the liquid line of descent from $\sim 1200{ }^{\circ} \mathrm{C}$ to $<910{ }^{\circ} \mathrm{C}$.

- Righter et al. (1998) demonstrate a $T-f_{2} \mathrm{O}_{2}$ trajectory parallel to FMQ over the course of magmatic differentiation from olivine basalt to rhyolite at Volcán Alcedo, Galápagos.

- Carmichael (1967) demonstrates the same trajectory for the basalt-to-rhyodacite series at Thingmuli, Iceland.
- Delano (2001) examines a large database for mid-oceanridge igneous suites and demonstrates that a $T-\mathrm{fO}_{2}$ trajectory parallel to FMQ is typical.

According to Carmichael (1991), this behavior is because (1) the magma chambers are effectively closed to $\mathrm{O}_{2}$ exchange with environs and (2) during cooling and crystallisation, the poly-phase cotectic mineral assemblage extracts $\mathrm{Fe}^{3+}$ and $\mathrm{Fe}^{2+}$ in essentially the same proportions as were present in the melt at the onset of $\mathrm{Fe}$-Ti-oxide precipitation. To the degree that a magmatic differentiation series evolves along such a trend of constant $\mathrm{Fe}^{3+} / \mathrm{Fe}^{2+}$ in the melt, it also evolves along a trend of essentially constant $\mathrm{Ce}^{4+} / \mathrm{Ce}^{3+}$ and $\mathrm{U}^{5+} / \mathrm{U}^{4+}$ in the melt, as shown in Fig. 3. In a following section, we introduce an independent, robust demonstration that igneous intrusions usually follow a liquid line of descent from basaltic-andesitic through dacitic compositions controlled by fractional crystallisation in a system closed to oxygen and hydrogen.

\section{Temperature-dependent lattice-strain influence on $\mathrm{M}^{4+}$ and $\mathrm{M}^{3+}$ partition coefficients}

Blundy and Wood (1994) introduced a method for estimating mineral-melt trace-element partition coefficients, based on the elasticity of the crystal lattice and the degree to which substituent ions of various sizes misfit the lattice sites of the host mineral. Their method extends to crystal-melt ionexchange reactions an expression derived by Brice (1975) that relates the mechanical strain energy, $\Delta G_{\text {strain }}$, around a size-mis-fitting ion to the elasticity (Young's Modulus, $E$ ) of the host crystal:

$$
\begin{aligned}
\Delta G_{\text {strain }} & =4 \pi \mathrm{EN}_{\mathrm{A}}\left[\left(r_{\mathrm{o}} / 2\right)\left(r_{i}-r_{\mathrm{o}}\right)^{2}+1 / 3\left(r_{i}-r_{\mathrm{o}}\right)^{3}\right]_{(2)} \\
& \approx-\operatorname{RT} \ln \left(D_{i}^{\mathrm{z} / \mathrm{m}} / D_{o}^{\mathrm{z} / \mathrm{m}}\right)
\end{aligned}
$$

wherein ion radius $r_{i}$ and partition coefficient $D_{i}$ refer to the substituent element $i$ in zircon (z) and melt (m), and $r_{\mathrm{o}}$ and $D_{\mathrm{o}}$ refer to an element that is an ideal, strain-free fit in the lattice site. $N_{\mathrm{A}}$ is Avogadro's number, $R$ is the gas constant, and $T$ is in kelvins. This relation is of the same form as the familiar relation between the Gibbs energy and equilibrium constant for an ion-exchange reaction, $\Delta G^{\circ}=-R T$ In $K_{\text {exchg, }}$, but Nernst-type partition coefficients, $D_{\mathrm{i}}$ (in units of concentration by weight) can be used, because conversion factors for ppmw to mole fractions of components in zircon and melt cancel in the ratio. Division of Eq. (2) by RT yields a relation that illustrates the reciprocal variation of partition coefficients with temperature.

We apply Eq. (2) to zircon/melt partition coefficients reported for a series of tetravalent ions and trivalent ions, to evaluate $r_{\mathrm{o}}$ and $D_{\mathrm{o}}$ and $E$ by least-squares regression on 
each valence series. Ionic radii, $r_{i}$, are listed in Table 1 (from Shannon 1976). Figure 4a illustrates the results for a series of tetravalent and trivalent ions in the $\mathrm{Zr}$-dominated sublattice of zircon, as measured by ion probe on zircons and haplo-andesitic melt in experiments at $1300{ }^{\circ} \mathrm{C}$ and $1 \mathrm{~atm}$ and $\log \mathrm{fO}_{2} \leq \mathrm{FMQ}$ by Burnham and Berry (2012). Figure $4 \mathrm{a}$ also shows a series of partition coefficients, measured by ion probe on unpolished surfaces of natural zircon crystals and on enclosing rhyolitic volcanic glass, reported by Claiborne et al. (2018). Figure 4 a shows that parabolas fitted to the data are tighter for tetravalent ions than for trivalent ions at each temperature, and the parabolas are narrower at lower temperature, reflecting decrease in lattice-site elasticity with increasing ionic charge and with decreasing temperature.

Table 1 Effective ionic radii ( $\AA$ ) of cations in (A) eightfold coordination with oxygen that may substitute for $\mathrm{Zr}$ in zircon (Shannon 1976) and (B) fourfold coordination with oxygen that may substitute for $\mathrm{Si}$ in zircon (Shannon 1976)

\begin{tabular}{|c|c|c|c|c|}
\hline & M3+ & M4+ & M5+ & M6+ \\
\hline \multicolumn{5}{|c|}{ (A) Cations in eightfold coordination with oxygen } \\
\hline $\mathrm{Zr}$ & & 0.84 & & \\
\hline Hf & & 0.83 & & \\
\hline $\mathrm{Ti}$ & & 0.74 & & \\
\hline $\mathrm{Nb}$ & & & 0.74 & \\
\hline $\mathrm{Sc}$ & 0.87 & & & \\
\hline Th & & 1.05 & & \\
\hline $\mathrm{U}$ & & 1.00 & 0.90 & 0.86 \\
\hline $\mathrm{La}$ & 1.16 & & & \\
\hline $\mathrm{Ce}$ & 1.143 & 0.97 & & \\
\hline $\operatorname{Pr}$ & 1.126 & & & \\
\hline $\mathrm{Nd}$ & 1.109 & & & \\
\hline $\mathrm{Sm}$ & 1.079 & & & \\
\hline Gd & 1.053 & & & \\
\hline Dy & 1.027 & & & \\
\hline Y & 1.019 & & & \\
\hline Ho & 1.015 & & & \\
\hline $\mathrm{Er}$ & 1.004 & & & \\
\hline $\mathrm{Yb}$ & 0.985 & & & \\
\hline $\mathrm{Lu}$ & 0.977 & & & \\
\hline \multicolumn{5}{|c|}{ (B) Cations in fourfold coordination with oxygen } \\
\hline $\mathrm{Si}$ & & 0.26 & & \\
\hline B & 0.11 & & & \\
\hline $\mathrm{P}$ & & & 0.17 & \\
\hline$S$ & & & & 0.12 \\
\hline $\mathrm{Al}$ & 0.39 & & & \\
\hline $\mathrm{Ti}$ & & 0.42 & & \\
\hline $\mathrm{Fe}$ & 0.49 & & & \\
\hline $\mathrm{Nb}$ & & & 0.48 & \\
\hline
\end{tabular}

The similarities of the radius of $\mathrm{U}^{4+}$ with $\mathrm{Ce}^{4+}$ and of $\mathrm{Pr}^{3+}$ with $\mathrm{Ce}^{3+}$ are highlighted in boldface
Least-squares fits of Eq. (2) to those and other volcanic samples described by Claiborne et al. (2018) yield the parameters listed in Table 2. The derived values in Table 2 for the "ideal fit" ion size, $r_{\mathrm{o}}$, and for the Young's Modulus, $E^{\mathrm{M}+}$, for felsic volcanic samples are similar to the values $r_{0}^{4+}$ $=0.912 \AA, E^{4+} \approx 750 \mathrm{GPa}, r_{\mathrm{o}}^{3+}=0.962 \AA$, and $E^{3+} \approx 620$ GPa derived by Blundy and Wood (2003) for a zircon-glass pair from a natural rhyolite. A strong trend of increasing $D_{0}$ values (apex of the parabolas) and $D_{\mathrm{Ce}_{4}}^{\mathrm{z} / \mathrm{m}}$ values with decreasing temperature is evident; a weak tendency for $E$ values and $D_{\mathrm{Ce}_{3}}^{z / m}$ to increase with decreasing temperature is suggested. In the case of mis-fitting trivalent ions, there is a competition between the tendency of crystal/melt partition coefficients to increase with decreasing temperature, and the increasing inability of the lattice to deform to accommodate them as temperature decreases. Figure $4 \mathrm{~b}$ shows a plot of zircon/melt partition coefficients of $\mathrm{Ce}^{4+}$ and $\mathrm{Ce}^{3+}$ (Table 2) at the experimental temperature $1300{ }^{\circ} \mathrm{C}$ or at the zircon-saturation temperature reported by Claiborne et al. for natural zircon-glass pairs. Dispersion of the data for volcanic suites is due mainly to uncertainty in experimental calibration of the zircon-saturation geothermometer (around $\pm 15^{\circ} \mathrm{C}, 1 \sigma$; Hanchar and Watson 2003), and due to micrometer-scale compositional zoning in analysis spots $15 \mu \mathrm{m}$ diameter on "rims" of natural crystals in samples IHB, ITHn, and HRL21. Natural surfaces of zircon crystals were analysed in SHL samples. Magma chamber replenishments and mixing preceding and accompanying volcanic eruptions may, in some cases, cause mis-match of zircon crystals with the melt from which they grew. Least-squares regression of the array in Fig. 4b yields the equation: $\log \left(D_{\mathrm{Ce}_{4}}^{\mathrm{z} / \mathrm{m}} / D_{\mathrm{Ce}_{3}}^{\mathrm{z} / \mathrm{m}}\right)=-2.34+0.9639 \times$ $10^{4} / \mathrm{T}(\mathrm{K}) ; R=0.93$.

In Fig. $4 \mathrm{a}$, the measured values of $D_{\mathrm{U}}^{\mathrm{z} / \mathrm{m}}$ plot below the parabolas fitted to other tetravalent ions. Blundy and Wood (2003), Ballard et al. (2002), and others have noted the same sense of deviation of measured of $D_{\mathrm{U}}^{\mathrm{z} / \mathrm{m}}$ from the value predicted for $\mathrm{U}^{4+}$ in natural zircons from peralkaline and metaluminous rocks. The deviation may be due to incorporation of a minor proportion of the uranium as $\mathrm{U}^{5+}$ in zircon via the charge-coupled substitution $2 \mathrm{Zr}^{4+} \leftrightarrow \mathrm{REE}^{3+}+\mathrm{U}^{5+}$. Burnham and Berry (2017) report that zircons from peraluminous S-type granites have phosphorus contents near the amounts expected for charge balance of the measured abundances of $\mathrm{Y}+\mathrm{REE}^{3+}$ according to the charge-coupled substitution $\mathrm{Zr}^{4+}$ $+\mathrm{Si}^{4+} \leftrightarrow \mathrm{REE}^{3+}+\mathrm{P}^{5+}$, but they report that zircons from metaluminous I-type granitoids have a systematic deficit of charge-balancing phosphorus. This is understandable in light of experiments by Pichavant et al. (1992) showing that, at a given temperature and pressure and $\mathrm{wt} \% \mathrm{H}_{2} \mathrm{O}$ in the melt, apatite solubility and phosphorus content of silicate melts increase dramatically with increasing $\mathrm{Al} /(\mathrm{Ca}+\mathrm{Na}+\mathrm{K})$, due 


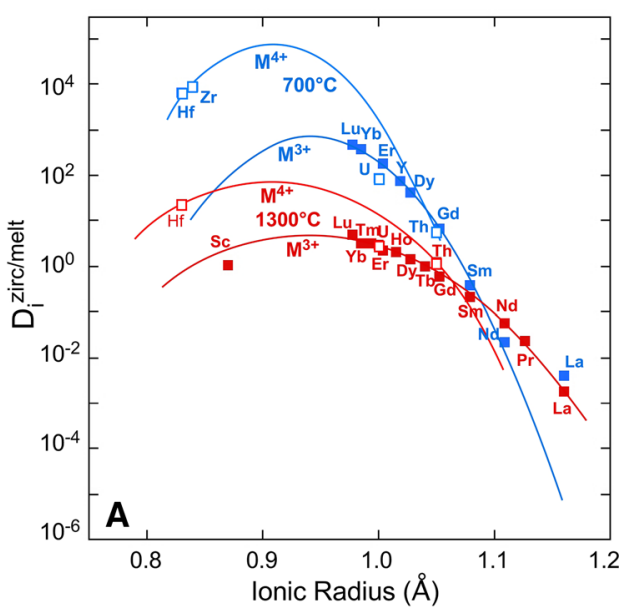

Fig. 4 a Comparison of predicted (lines) and observed (symbols) zircon/melt partition coefficients for tetravalent and trivalent ions occupying the $\mathrm{Zr}$-dominated sublattice in zircon. Blue symbols represent ion-probe measurements $1-2 \mu \mathrm{m}$ deep on the natural surface of zircon crystals and enclosing volcanic glass from Mt. St. Helens (sample SHL-26Z), reported by Claiborne et al. (2018), using their zircon-saturation temperature $\left(703 \pm 20{ }^{\circ} \mathrm{C} ; 1 \sigma\right.$; calibration of Watson and Harrison 1983). Red symbols represent ion-probe analyses of zircon rims and enclosing haplo-andesitic glass produced in experiments at 1300 ${ }^{\circ} \mathrm{C}$ and 1 atm by Burnham and Berry (2012). Ionic radii are from Shannon (1976). b Temperature dependence of $\mathrm{Ce}^{4+} / \mathrm{Ce}^{3+}$ fractiona-

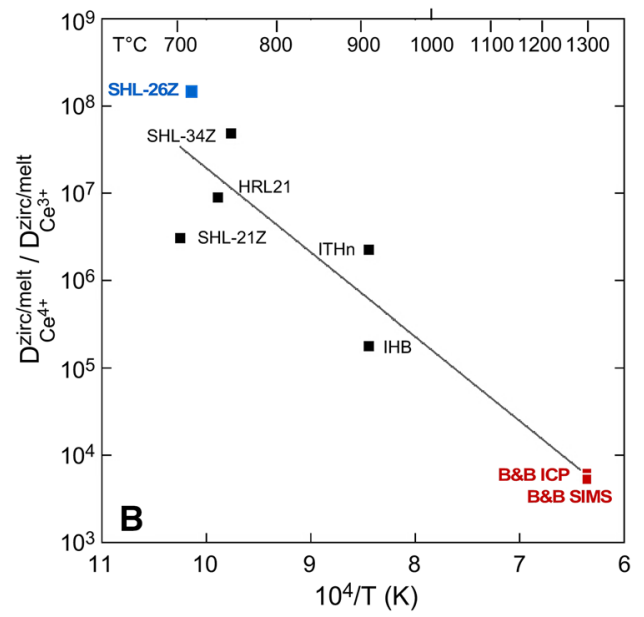

tion between zircon and melt due to lattice strain, as represented by variation of the zircon/melt partition coefficients of $\mathrm{Ce}^{4+}$ and $\mathrm{Ce}^{3+}$ with temperature, determined by least-squares fitting (as in a) of Eq. (2) to partition coefficients and zircon-saturation temperatures reported for natural phenocryst-glass pairs by Claiborne et al. (2018) (black and blue symbols; standard errors not reported) and fitted to experimental $\left(1300^{\circ} \mathrm{C}\right)$ zircon/melt partition coefficients analysed by SIMS and by LA-ICPMS by Burnham and Berry (2012). Leastsquares regression yields the equation: $\log \left(D_{\mathrm{Ce}_{4}}^{\mathrm{z} / \mathrm{m}} / D_{\mathrm{Ce}_{3}}^{\mathrm{z} / \mathrm{m}}\right)=$ $-2.34+0.9639 \times 10^{4} / T(\mathrm{~K}) ; R=0.93$
Table 2 Best fit parameters for Eq. (2) applied to experimental partition data (B\&B-SIMS, B\&B-ICP) from Burnham and Berry (2012) and to chemical analyses of natural zircon/glass pairs (other samples) from Claiborne et al. (2018)

\begin{tabular}{lrllllllrr}
\hline Sample & $T\left({ }^{\circ} \mathrm{C}\right)$ & $r_{\mathrm{o}}{ }^{3+}(\AA)$ & $\mathrm{D}_{\mathrm{o}}{ }^{3+}$ & $D_{\mathrm{Ce}_{3}}^{z / m}$ & $\mathrm{E}^{3+}(\mathrm{GPa})$ & $r_{\mathrm{o}}{ }^{4+}(\AA)$ & $D_{\mathrm{o}}{ }^{4+}$ & $\mathrm{E}^{4+}(\mathrm{GPa})$ & $D_{\mathrm{Ce}_{4}}^{z / m}$ \\
\hline B\&B-SIMS & 1300 & 0.94 & 4.6 & $6.4 \times 10^{-3}$ & 513 & 0.91 & 71 & 718 & 35 \\
B\&B-ICP & 1300 & 0.94 & 4.0 & $5.1 \times 10^{-3}$ & 520 & 0.91 & 59 & 695 & 30 \\
ITHN & 910 & 0.94 & 196 & $5.8 \times 10^{-3}$ & 611 & 0.91 & 2521 & 683 & 1027 \\
IHB & 910 & 0.94 & 124 & $6.8 \times 10^{-4}$ & 711 & 0.91 & 4941 & 895 & 1522 \\
SHL-34Z & 751 & 0.94 & 744 & $1.8 \times 10^{-4}$ & 774 & 0.91 & 35,242 & 926 & 8623 \\
HRL21 & 738 & 0.94 & 719 & $8.3 \times 10^{-4}$ & 685 & 0.91 & 21,588 & 685 & 7517 \\
SHL-26Z & 713 & 0.94 & 702 & $1.0 \times 10^{-4}$ & 771 & 0.91 & 77,111 & 1044 & 14,841 \\
SHL-21Z & 703 & 0.94 & 828 & $4.6 \times 10^{-3}$ & 585 & 0.91 & 62,944 & 928 & 14,340 \\
\hline
\end{tabular}

Also shown are zircon/melt partition coefficients of $\mathrm{Ce}^{3+}$ and $\mathrm{Ce}^{4+}$ in each sample, obtained from parabolic fits to other $\mathrm{M}^{3+}$ and $\mathrm{M}^{4+}$ ions, respectively to increase of $\mathrm{Ca}-\mathrm{Al}$ complexing in the melt with increasing $\mathrm{A} / \mathrm{CNK}$. Therefore, in metaluminous melts with higher lime activity and lower phosphate activity at apatite saturation, other charge-balancing mechanisms are implicated for incorporation of $\mathrm{REE}^{3+}$ into zircon. Ionic radii in Table 1 suggest that $\mathrm{U}^{5+}$ should be a lower strain candidate for that charge-coupled substitution role than, say, $\mathrm{Nb}^{5+}, \mathrm{Ta}^{5+}$, or $\mathrm{V}^{5+}$. Variation of the charge-coupled substitution mechanism with melt $\mathrm{A} / \mathrm{CNK}$ is expected to diminish a correlation of $\mathrm{E}^{3+}$ with temperature in Table 2.

\section{Cooling-induced variation of $\mathrm{Ce}^{4+} / \mathrm{Ce}^{3+}$ and $\mathrm{U}^{5+} / \mathrm{U}^{4+}$ in zircon at constant ratios in the melt}

In Fig. 5, we present new measurements illustrating strongly temperature-dependent variation of $\mathrm{Ce}^{4+} / \mathrm{Ce}^{3+}$ in a natural zircon assemblage from a calc-alkalic volcanic arc suite. A few drill-core and outcrop samples of eruptive andesites and dacites from the Tampakan volcanic complex are sufficiently free of hydrothermal alteration to permit application of the titanomagnetite-ilmenite geothermometer (calibration of Ghiorso and Evans 2008) and the plagioclase-hornblende geothermometer (calibration of Holland and Blundy 1994). New data for Tampakan phenocryst compositions that are 


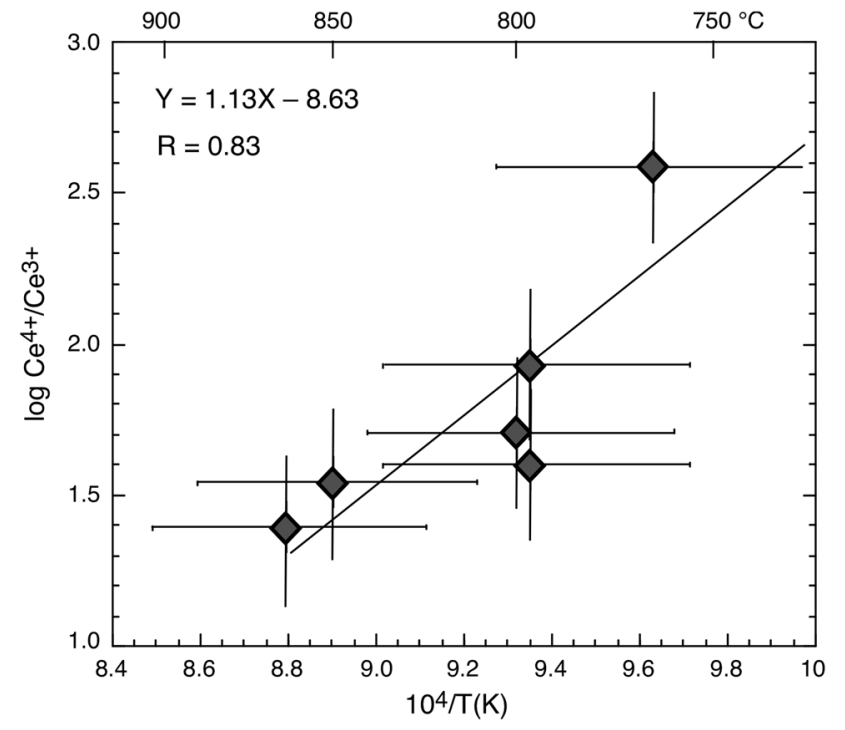

Fig. 5 For zircon-bearing silicic andesites and dacites from the Tampakan volcano, Mindanao, that are sufficiently free of hydrothermal alteration to permit geothermometry on associated phenocrysts, we combine whole-rock ICPMS analyses of trace elements with analyses of zircons by ArF ELA-ICPMS (Rohrlach 2002) to calculate zircon $\mathrm{Ce}^{4+} / \mathrm{Ce}^{3+}$ ratios by the lattice-strain method of Blundy and Wood (1994). Those $\mathrm{Ce}^{4+} / \mathrm{Ce}^{3+}$ ratios are plotted against temperatures obtained for the same samples on touching titanomagnetite-ilmenite phenocryst pairs (calibration of Ghiorso and Evans 2008) and on hornblende-plagioclase phenocryst pairs (calibration by Holland and Blundy 1994). Estimated uncertainty bars are $\pm 1 \mathrm{SE}$

represented in Figs. 1 and 5 are shown in Electronic Supplementary Materials 2 and 3. In a zircon-bearing subset of those samples, we use whole-rock trace-element analyses by ICPMS together with zircon compositions analysed by ArF ELA-ICPMS to calculate zircon $\mathrm{Ce}^{4+} / \mathrm{Ce}^{3+}$ ratios by the lattice-strain method of Blundy and Wood $(1994,2003)$. All available paired $\mathrm{T}-\mathrm{Ce}^{4+} / \mathrm{Ce}^{3+}$ data are plotted in Fig. 5, which shows strong lattice-strain discrimination, as the zircon lattice thermally contracts during growth from cooling magma, in favour of smaller, better-fitting $\mathrm{Ce}^{4+}$ relative to larger, size- and charge-mis-fitting $\mathrm{Ce}^{3+}$ ions in $\mathrm{Zr}^{4+}$ lattice sites. The $\mathrm{T}-\mathrm{fO}_{2}$ trend of Tampakan $\mathrm{Fe}-\mathrm{Ti}$ oxide data in Fig. 1 and trace-element compositions of Tampakan zircons presented ahead (Fig. 9) demonstrate that the Tampakan andesite-dacite series developed at essentially constant oxidation state of $\mathrm{Fe}, \mathrm{Ce}$, and $\mathrm{U}$ in the melt.

The effect of thermally modulated lattice strain on incorporation of $\mathrm{U}^{4+}, \mathrm{U}^{5+}, \mathrm{Ce}^{4+}, \mathrm{Ce}^{3+}$, and other trivalent lanthanides is illustrated in Fig. 6, wherein each panel shows a compilation of experimental results at varying temperature but constant pressure, constant bulk composition of the charge, and constant oxidation state of $\mathrm{Ce}$ and $\mathrm{U}$ in the melt. In each suite of experiments, those at the three highest temperatures are illustrated, as they are most likely to approximate equilibrium partitioning. Each panel shows experimentally determined zircon/melt partition coefficients of an ion, $\mathrm{U}^{4+}$ or $\mathrm{Ce}^{4+}$, that fits relatively well in the $\mathrm{Zr}^{4+}$ sublattice of zircon, and also shows partition coefficients of a larger ion that fits relatively poorly in the $\mathrm{Zr}^{4+}$ sublattice (see ionic radii in Table 1). In each panel of Fig. 6, the ratio of the better-fitting, smaller ion to poorer fitting, larger ion increases in zircon with decreasing temperature at constant redox state of the melt-including the ratio $\mathrm{Ce}^{4+} / \mathrm{Ce}^{3+}$ in zircon (Fig. 6d). All experiments were buffered at NNO, which is shown in Fig. 3 to correspond to effectively constant oxidation state of $\mathrm{U}$ and $\mathrm{Ce}$ in the melt. These experiments corroborate calculated results in Fig. 4 for temperature dependence of lattice-strain influence on zircon/melt partition coefficients of ions of various sizes.

In thoughtfully designed experimental studies aiming to calibrate $\mathrm{Ce}^{4+} / \mathrm{Ce}^{3+}$ in zircon as a magmatic oxybarometer, Trail et al. $(2011,2012)$ recognise substantial temperature dependence of zircon/melt partition coefficients of $\mathrm{Ce}^{3+}$ and $\mathrm{Ce}^{4+}$. However, zircon/melt disequilibrium partitioning is problematic in laboratory experiments (and in nature), as discussed by Luo and Ayers (2009), Hofmann et al. (2014), and Trail et al. (2015), so the temperature dependence has not been well characterised by laboratory experiments on granitoid magmas. However, Claiborne et al. (2018) address much of that deficiency by determination of zircon/glass partition coefficients in natural volcanic suites, coupled with zircon-saturation geothermometry to characterise the varying temperature dependence of zircon/melt partition coefficients for ions of charge $5+, 4+$, and $3+$.

\section{Effect of isothermally varying $\mathrm{fO}_{2}$ on relative incorporation of $\mathrm{Ce}$ and $\mathrm{U}$ by zircon}

Figure 7 illustrates the effect of varying magmatic $\mathrm{fO}_{2}$ on zircon/melt partition coefficients of $\mathrm{Ce}$ and $\mathrm{U}$ at constant pressure $(1 \mathrm{~atm})$ and temperature $\left(1300{ }^{\circ} \mathrm{C}\right)$ and constant elemental composition of the melt (Fe-free haplo-andesite). The experiments show that zircon/melt partition coefficients of $\mathrm{U}$ and $\mathrm{Ce}$ have opposite senses of variation in response to isothermally varying $\mathrm{fO}_{2}$. Zircon/melt partition coefficients of the charge-invariant elements $\mathrm{La}, \mathrm{Pr}, \mathrm{Nd}, \mathrm{Sm}, \mathrm{Gd}$ and heavier REEs do not vary over that range of $f_{2}$. Therefore, within the $\log f \mathrm{O}_{2}$ range FMQ-2 to FMQ+5 that is relevant to most terrestrial magmas, nearly all $\mathrm{Ce}$ in zircon is $\mathrm{Ce}^{4+}$, and the element ratios $\mathrm{U} / \mathrm{Pr}$ and $\mathrm{Ce} / \mathrm{Nd}$ show opposite variation trends. Ce/Nd is a proxy for $\mathrm{Ce}^{4+} / \mathrm{Ce}^{3+}$ in these experiments, in which Ce valence was not measured (Fig. 7). Although the bulk composition of experimental charges includes an ample supply of $\mathrm{Sc}^{3+}, \mathrm{Y}^{3+}$ and $\mathrm{REE}^{3+}$ and of $\mathrm{P}^{5+}, \mathrm{Nb}^{5+}$ and $\mathrm{Ta}^{5+}$ ions that could team up for coupled substitutions of the type $2 \mathrm{Zr}^{4+} \leftrightarrow \mathrm{M}^{3+}+\mathrm{M}^{5+}$ or $\mathrm{Zr}^{4+}+$ $\mathrm{Si}^{4+} \leftrightarrow \mathrm{M}^{3+}+\mathrm{M}^{5+}$, the trends of zircon/melt partition coefficients of $\mathrm{Ce}$ and $\mathrm{U}$ demonstrate that coupled substitutions of 


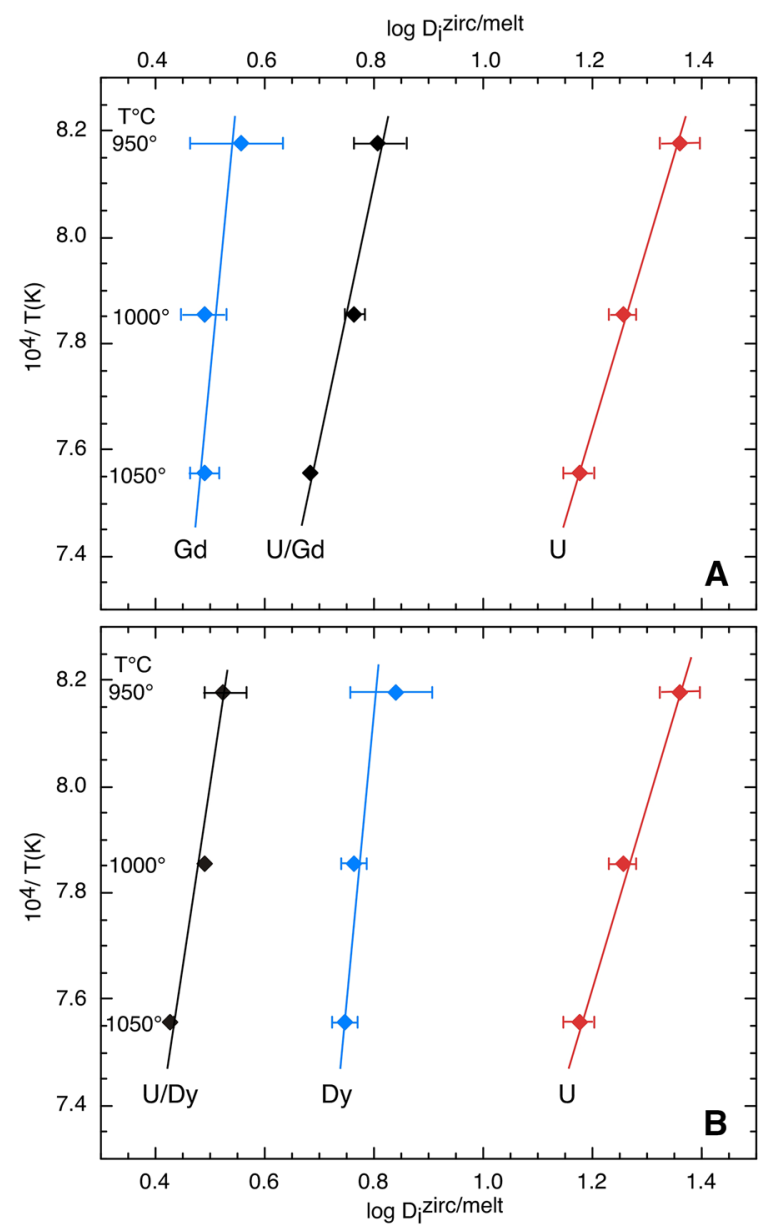

Fig. 6 Experimental determinations of the effect of varied temperature on zircon/melt partition coefficients $\left(D_{i}{ }^{\text {zirc/melt }}\right)$ of $\mathrm{U}, \mathrm{Ce}, \mathrm{La}, \mathrm{Pr}$, $\mathrm{Gd}$, and Dy in experiments in which $\mathrm{fO}_{2}$ was buffered by $\mathrm{Ni}+\mathrm{NiO}$, at constant pressure, and nearly constant major-element composition of the hydrous granitoid melts. In each panel, the element that is most compatible in zircon is red; the element least compatible in zircon is blue. In each panel the ratio of the better-fitting ion to the poorer fitting ion rises with decreasing temperature. a, b Experimen-

charge- and size-misfitting ions are strongly disfavoured by zircon. The variation trends can be described by a sigmoid function, as derived by Burnham and Berry (2012).

Burnham and Berry (2012) question the validity of the $\mathrm{U}$ trend in Fig. 7 because of suspected (but unsubstantiated) volatilisation of $\mathrm{UO}_{3}$ from the melt in the 1-atm gas-flow furnace used for these experiments. However, Luo and Ayers (2009) document the same trend of $D_{\mathrm{U}}^{\text {zirc/melt }}$ in experiments in sealed capsules in cold-seal pressure vessels at $2 \mathrm{kbar}$ and $800{ }^{\circ} \mathrm{C}$ spanning $9 \log$ units $f \mathrm{O}_{2}$. They report $D_{\mathrm{U}}^{\text {zirc/melt }}=32$ on the wüstite + iron buffer $(=\mathrm{FMQ}-4.0) ; D_{\mathrm{U}}^{\text {zirc/melt }}=20$ on the nickel + nickel-oxide buffer ( $=\mathrm{FMQ}+0.84)$; and $D_{\mathrm{U}}^{\text {zirc/melt }}$ $=3.3$ on the hematite + magnetite buffer $(=\mathrm{FMQ}+5.05)$. That 10 -fold range in $D_{\mathrm{U}}^{\text {zirc/melt }}$ is the same as in the equivalent $\triangle F M Q$ range in Fig. 7. Various spectroscopic methods

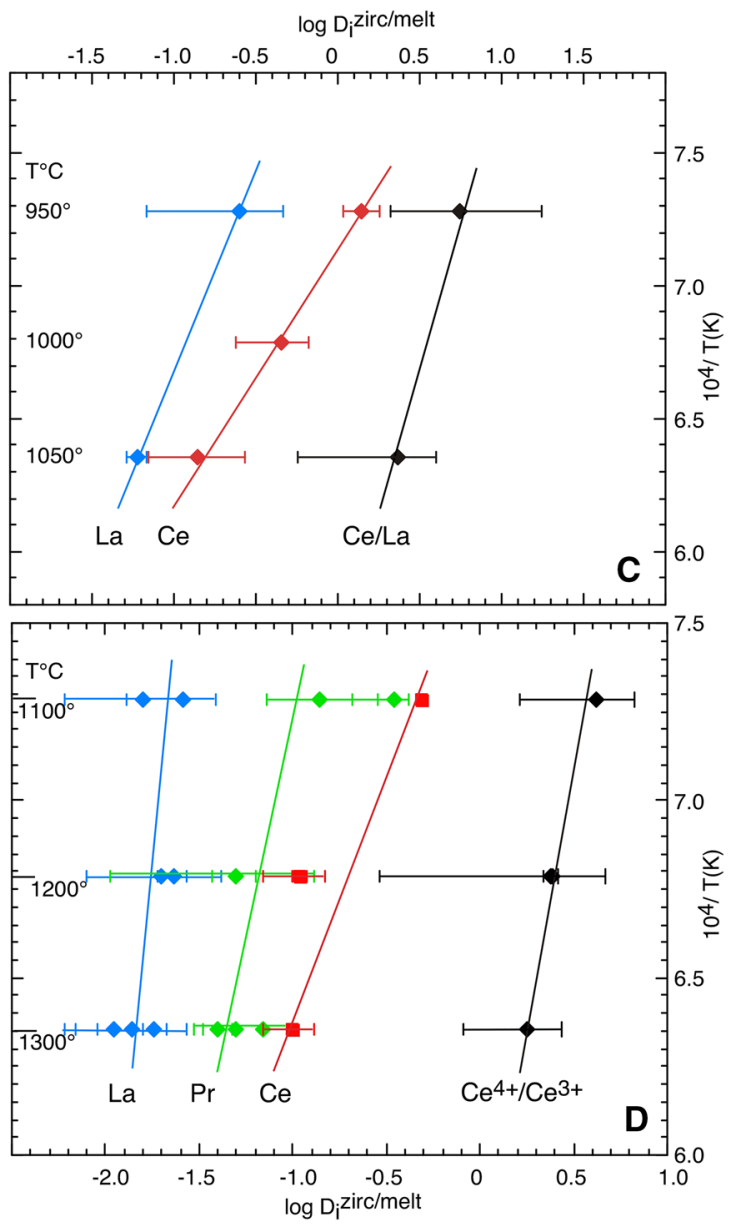

tal results by Rubatto and Hermann (2007) in hydrous peraluminous tonalite, 66.1-69.8 wt\% $\mathrm{SiO}_{2}$ at $20 \mathrm{kbar}$ and $\mathrm{fO}_{2}$ buffered at NNO. c Experimental results by Luo and Ayers (2009) in hydrous peralkaline granite, 68.0-70.3 wt $\% \mathrm{SiO}_{2}$ at $15 \mathrm{kbar}$ and $\mathrm{fO}_{2}$ on the NNO buffer; $d$ experimental results by Trail et al. (2012) in peraluminous haplo-granitic melt at $10 \mathrm{kbar}$, showing an increase in the zircon's $\mathrm{Ce}^{4+} / \mathrm{Ce}^{3+}$ ratio with decreasing temperature at constant redox state of $\mathrm{Ce}$ in the melt on the NNO buffer

have been employed by Schreiber and Andrews (1980), Farges et al. (1992) and Berry et al. (2008) to demonstrate that the oxidation of $\mathrm{U}^{4+}$ to $\mathrm{U}^{6+}$ in the melt proceeds via a $\mathrm{U}^{5+}$ intermediate stage which has a predominance range a bit above FMQ at magmatic temperatures.

\section{Introduction of zircon $\mathrm{U} / \mathrm{Pr}$ versus $\mathrm{Ce}^{4+} / \mathrm{Ce}^{3+}$ plots}

The experiments reported in Fig. 7 demonstrate that, at oxidation states of common terrestrial magmas, essentially all $\mathrm{Ce}$ in zircon occurs as $\mathrm{Ce}^{4+}$ and nearly all $\mathrm{U}$ as $\mathrm{U}^{4+}$. We introduce plots of $\mathrm{U} / \mathrm{Pr}$ versus $\mathrm{Ce}^{4+} / \mathrm{Ce}^{3+}$ in zircon to discriminate whether $\mathrm{Ce}^{4+} / \mathrm{Ce}^{3+}$ variations in zircon are due to redox variations in the melt during zircon crystallisation and/ or due to temperature-regulated fractionation of $\mathrm{Ce}^{4+}$ from 


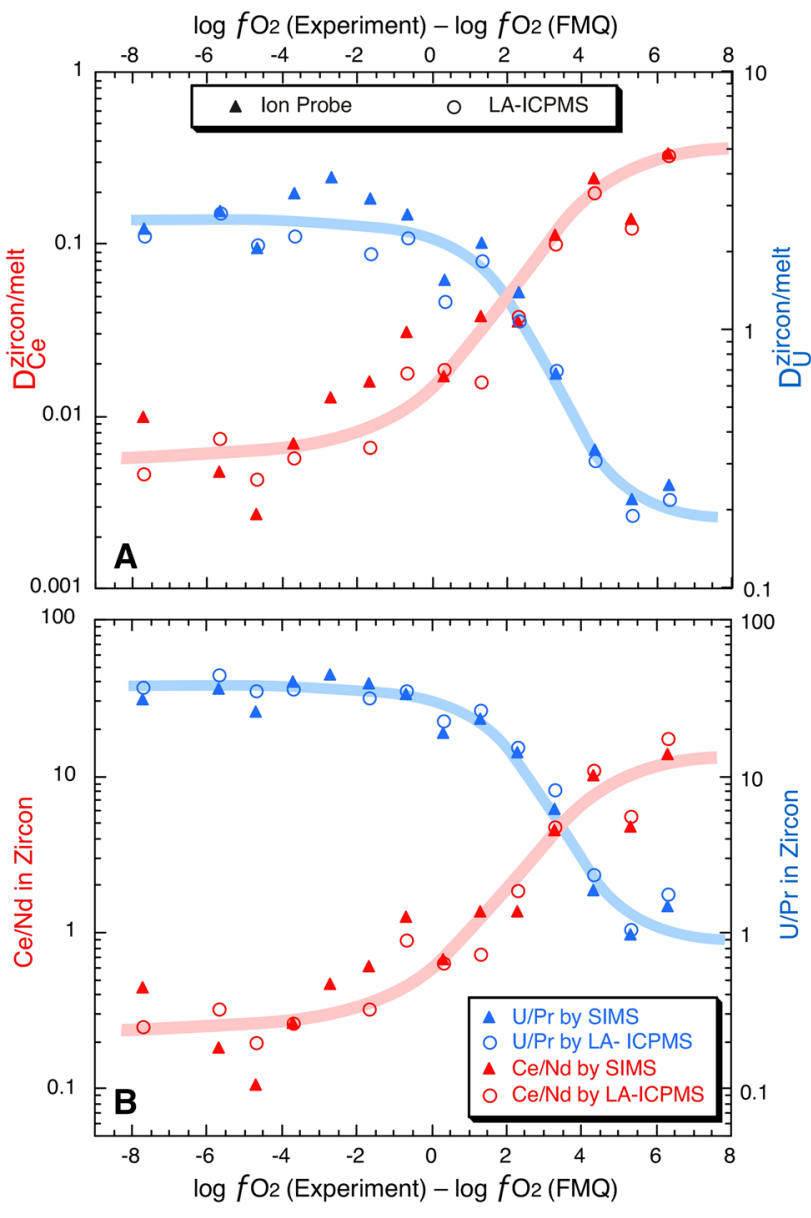

Fig. 7 Nernst partition coefficients of $\mathrm{Ce}$ and $\mathrm{U}$ and other trace elements between zircon and synthetic andesitic melt were measured by secondary-ion mass spectrometry (SIMS, ion probe) and by LAICPMS in Burnham and Berry's (2012) experiments at $1300{ }^{\circ} \mathrm{C}$ and $14 \log$ units variation of oxygen fugacity relative to the fayalite-magnetite-quartz reference buffer (FMQ). a Oxidation state of cerium varies from entirely $\mathrm{Ce}^{3+}$ in melt at the lowest $\mathrm{fO}_{2}$ to increased (but still small) amounts of $\mathrm{Ce}^{4+}$ in the melt at the highest $\mathrm{fO}_{2}$, over which range the $\mathrm{Ce}$ content of zircon rises $\sim 100$-fold as the proportion of $\mathrm{Ce}^{4+}$ in the melt increases. Uranium shows the opposite trend, being entirely $\mathrm{U}^{4+}$ in the melt at the lowest $\mathrm{fO}_{2}$, but with increasing amounts of $\mathrm{U}^{5+}$ the melt as $\mathrm{fO}_{2}$ increases. The data show a very strong preference for $\mathrm{U}^{4+}$ in $\mathrm{Zr}^{4+}$ lattice sites, and the zircon/melt partition coefficient of $U$ declines approximately 20 -fold as the melt's supply of $\mathrm{U}^{4+}$ diminishes with rising $\mathrm{fO}_{2}$. Burnham and Berry report standard errors of $D_{\mathrm{Ce}}^{z / m}$ that average $\pm 74 \%$ of the measured value; average standard errors of $D_{\mathrm{U}}^{\mathrm{z} / \mathrm{m}}$ are $\pm 34 \%$ of the measured values. b $\mathrm{Ce} / \mathrm{Nd}$ ratio in zircon (a proxy for $\Sigma \mathrm{Ce} / \mathrm{Ce}^{3+}$ in this experimental dataset in which $\mathrm{Ce}$ valence was not reported) rises approximately 100 -fold over the experimental $\mathrm{fO}_{2}$ range, while $\mathrm{U} / \mathrm{Pr}$ in zircon declines by a factor of about 20

$\mathrm{Ce}^{3+}$ by lattice strain. Table 1 shows that the ionic radius of $\mathrm{U}^{4+}$ in eightfold coordination with oxygen is $1.00 \AA$, very similar to that of $\mathrm{Ce}^{4+}, 0.97 \AA$, and shows that the $\mathrm{U}^{4+} / \mathrm{Pr}^{3+}$ ionic radius ratio, 0.888 , is very similar to the $\mathrm{Ce}^{4+} / \mathrm{Ce}^{3+}$ ionic radius ratio, 0.849 . Therefore, the effect of temperature variation on the relative zircon/melt partition coefficients of these ratios must be nearly identical. The close similarity of ionic radii of $\mathrm{Pr}^{3+}$ and $\mathrm{Ce}^{3+}$ is the rationale for choosing $\mathrm{Pr}$ as a denominator element. However, those ratios in zircon vary oppositely in response to $\mathrm{fO}_{2}$ variation, as indicated in Fig. 7b. This test of T- $\mathrm{fO}_{2}$ trends during magmatic differentiation is applicable to slowly cooled intrusive rocks, and it can test the reliability of $\mathrm{T}-\mathrm{fO}_{2}$ trends recovered from titanomagnetite-hemoilmenite phenocryst pairs in volcanic rocks. The Fe-Ti-oxide oxybarometer-thermometer is reliably applicable only to quickly quenched volcanic rocks, inasmuch as $\mathrm{Fe}-\mathrm{Ti}$ oxides re-equilibrate on the time scale of days to weeks at near-solidus temperatures (Venezky and Rutherford 1997).

\section{Magmatic redox trends from zircon U/Pr versus $\mathrm{Ce}^{4+} / \mathrm{Ce}^{3+}$ plots}

\section{Analytical and computational methods and sources of data dispersion}

Electronic Supplementary Material 3 lists previously unpublished analyses of zircons from the Tampakan volcanic complex, Mindanao, done by ArF ELA-ICPMS at the Research School of Earth Sciences, Australian National University. In following paragraphs, we show zircon $\mathrm{U} / \mathrm{Pr}$ versus $\mathrm{Ce}^{4+} /$ $\mathrm{Ce}^{3+}$ derived from ion-probe and LA-ICPMS analyses that were compiled from the literature and combined with our data for the Tampakan complex. Calculation of $\mathrm{Ce}^{4+} / \mathrm{Ce}^{3+}$ by the lattice-strain method of Blundy and Wood (1994, 2003) utilises zircon/melt partition coefficients obtained by combining analyses of zircon crystal rims or surfaces with analyses of associated glass (in volcanic suites) or with analyses of host whole rocks (in intrusive suites).

Zircons in all suites in the following data plots have complex oscillatory growth bands and sector zoning similar to that of Bishop Tuff zircon in Fig. 8. There is evidence from synthetic and natural zircons that very slow diffusion of high-electric-field-strength ions of charge $3+, 4+$ and $5+$ through a microns-thick melt boundary layer adjacent to a growing zircon crystal surface results in disequilibrium between the boundary-layer melt film and the bulk melt, and hence between zircon and bulk melt; that diffusional disequilibrium causes oscillatory compositional zoning of zircon at sub-micron to tens-of-microns scale (Luo and Ayers 2009). Such disequilibrium oscillations in composition are likely to be especially pronounced in zircons that grew from very viscous, $\mathrm{H}_{2} \mathrm{O}$-poor, high-silica rhyolitic melts, as documented in the Younger Toba Tuff and Bishop Tuff by Hofmann et al. (2014). There is also persuasive evidence that the zircon/ melt partition coefficients of high-field-strength elements vary between prism and various pyramidal crystal faces along the same growth band in zircon, as demonstrated by 


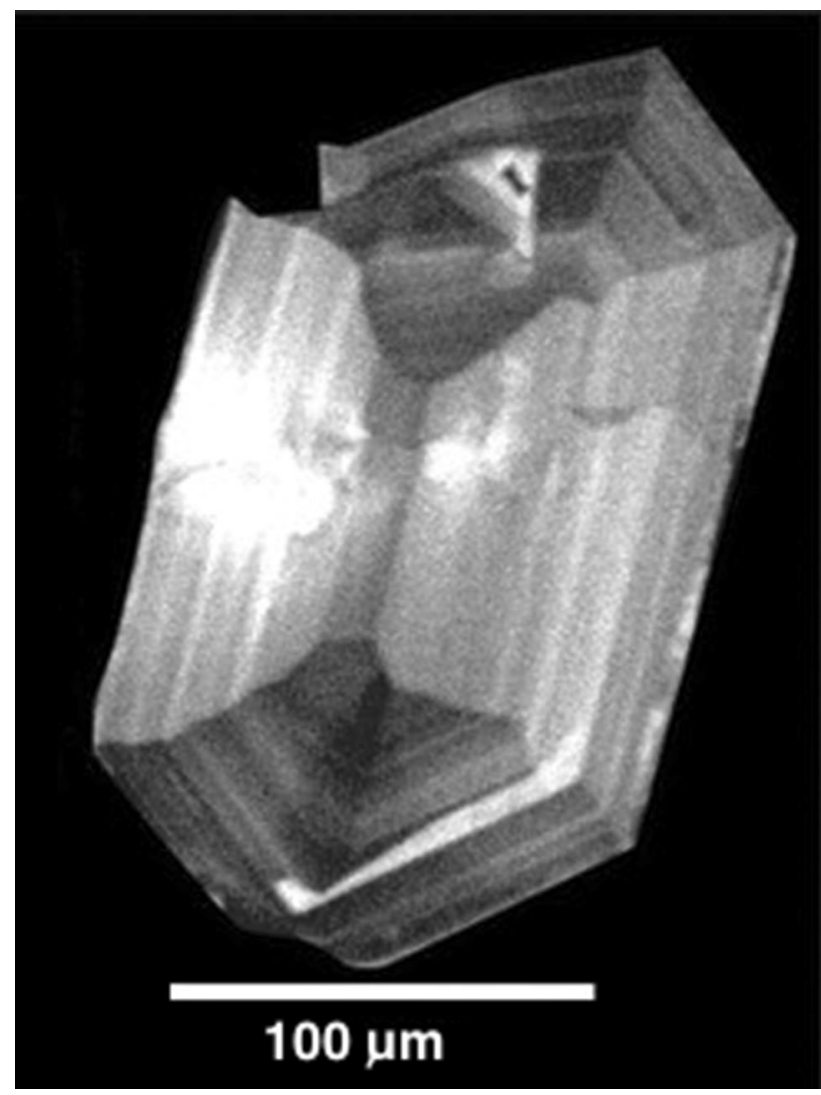

Fig. 8 Cathodoluminescence image showing oscillatory banding and sector zoning of zircons in the Bishop Tuff (after Crowley et al. 2007), which have been shown by Hofmann et al (2014) and Chamberlain et al. (2014) to correspond to significant variations of traceelement composition from band to band within a sector, and from sector to sector along individual growth bands. The outer oscillatory growth bands are narrower than the usual 10-30 $\mu \mathrm{m}$ diameter of ionprobe or LA-ICPMS beam spot analyses on zircon "rims", so such heterogeneity contributes dispersion to arrays of precise analyses in Figs. 9, 10, and 11

Tailby et al. (2011) and in Bishop Tuff zircons by Chamberlain et al. (2014). Although all utilised zircon analyses in Figs. 9, 10, and 11 are described by the respective data sources as "rims", the compositional heterogeneity within outer growth bands can be substantial at the 15-30 $\mu \mathrm{m}$ scale of ion-probe and LA-ICPMS beam spots. This contributes scatter to the zircon composition arrays that exceeds instrumental analytical errors on homogeneous material. However, the data dispersion within zircon arrays typically does not substantially exceed the dispersion within Fe-Ti-oxide arrays for volcanic suites in Fig. 1. Dispersion of zircon and $\mathrm{Fe}$-Ti-oxide compositions within volcanic suites is in many cases due in part to chamber replenishments and magma mixing immediately preceding the eruptions, as documented for the Bishop Tuff, Younger Toba Tuff, and Yellowstone supereruptions, among others (Evans and Bachmann 2013; Chesner and Luhr 2010; Wotzlaw et al. 2015). Eruption of inhomogeneous melt contributes some uncertainty in identifying equilibrium pairs of zircon rims and host glass in those volcanic suites.

\section{Suites showing no change in oxidation state during cooling}

Electronic Supplementary Material 3 lists Tampakan zircon trace-element analyses by ArF ELA-ICPMS at the Research School of Earth Sciences, Australian National University. Our analyses of Tampakan zircons have been combined with our compilation from published literature of zircon compositions in all igneous suites for which $\mathrm{Ce}^{4+} / \mathrm{Ce}^{3+}$ in zircon was calculated by the respective authors using the lattice-strain method, and which have enough data points to perform a test of trend. No examples were found that show a negative correlation of $\mathrm{U} / \mathrm{Pr}$ with $\mathrm{Ce}^{4+} / \mathrm{Ce}^{3+}$, as would represent variation of $\mathrm{Ce}^{4+} / \mathrm{Ce}^{3+}$ dominated by changing oxidation state of the melt. Figure 9 shows strong positive correlations of zircon $\mathrm{Ce}^{4+} / \mathrm{Ce}^{3+}$ with U/Pr in eight igneous complexes. In each of them, the regression slope is near 1.0, which means that the variations in both ratios are attributable entirely to cooling during crystallisation. Accordingly, there is no resolvable variation in redox state of the melt (as represented by redox indicators in Fig. 3) within any zircon suite shown in Fig. 9, including the Tampakan suite that is also illustrated in Fig. 5. Of the igneous suites represented in Fig. 9, the Tampakan volcanic suite is the only one for which analyses of Fe-Ti-oxide phenocrysts are available for independent corroboration of the $\mathrm{T}-\mathrm{fO}_{2}$ trend (Electronic Supplementary Material 2). The Tampakan $\mathrm{Fe}-\mathrm{Ti}$ oxide $\mathrm{T}-\mathrm{fO}_{2}$ array in Fig. 1 shows no resolvable change in oxidation state of the melt over the $920-705^{\circ} \mathrm{C}$ temperature interval, which corroborates the redox independence of the Tampakan zircon trend in Fig. 9 showing 1:1 co-variation of U/Pr with $\mathrm{Ce}^{4+} / \mathrm{Ce}^{3+}$.

\section{Suites showing oxidation during cooling}

In Fig. 10, we show a collection of zircon analyses from rhyolitic flow domes at South Sister volcano (Cascade arc) and from the $3.5 \mathrm{ka}$ Yn tephra erupted from Mt St Helens (Cascade arc) and from six subduction-related calc-alkalic intrusions. All except South Sister and Montecristo are "adakitic" (high $\mathrm{Sr} / \mathrm{Y}$ and $\mathrm{La} / \mathrm{Yb}$, modest or no Eu anomaly in the whole-rock REE pattern). Montecristo is a pre-ore intrusion in the Chuquicamata district. The chondrite-normalised REE patterns of the South Sister's Devil's Hills rhyolite lava domes are "adakite-like", steeply dipping, with a minimum at $\mathrm{Ho}$ and $\mathrm{La}_{\mathrm{N}} / \mathrm{Yb}_{\mathrm{N}}=14$ and $\mathrm{Eu} / \mathrm{Eu}^{*}=0.96$ to 0.97 in the two rock analyses reported by Stelten and Cooper (2012).

All the $\mathrm{Ce}^{4+} / \mathrm{Ce}^{3+}$ values plotted in Fig. 10 are those reported in the cited publications (following the calculation 

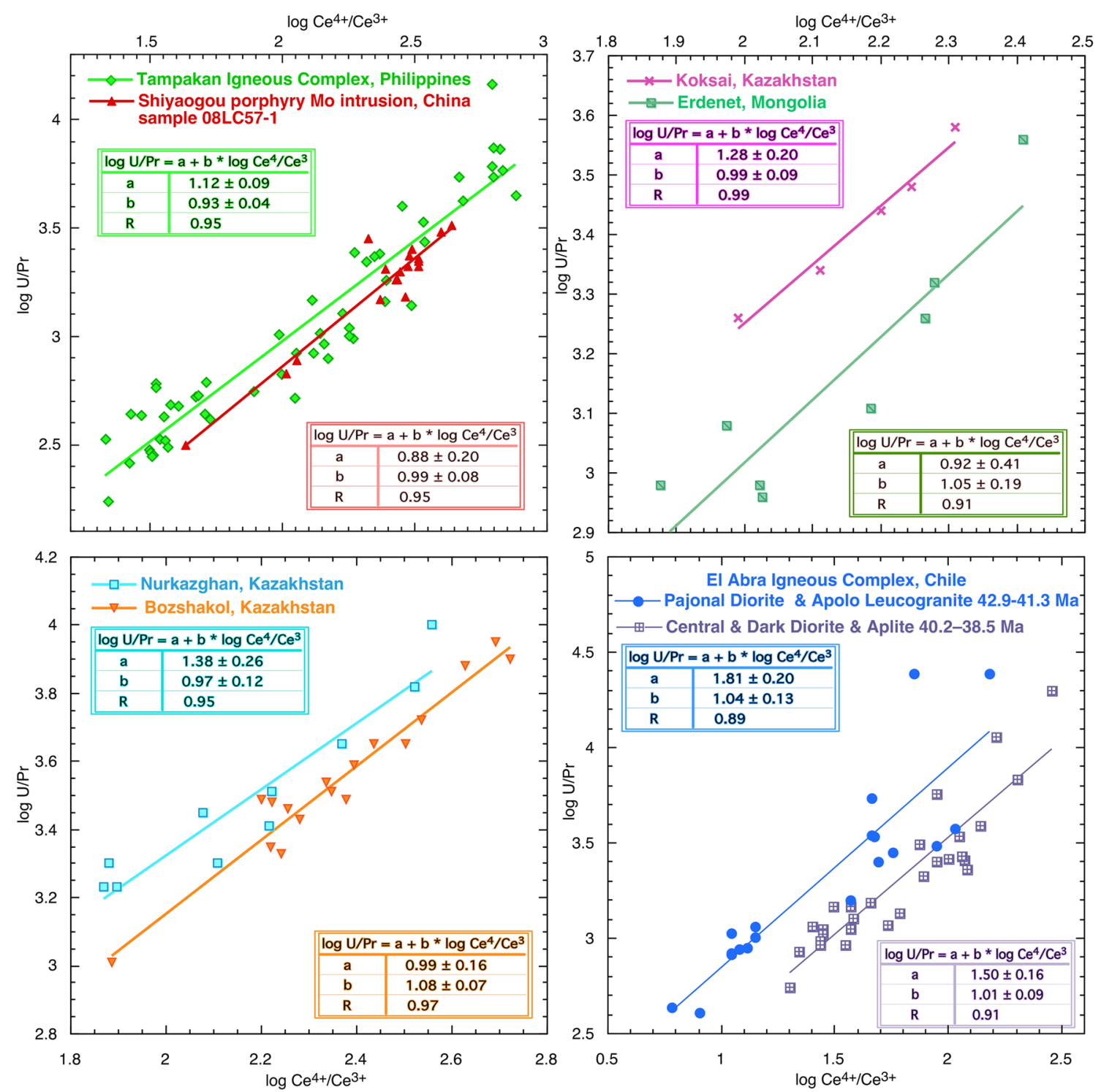

Fig. $9 \mathrm{Ce}^{4+} / \mathrm{Ce}^{3+}$ ratios in zircons (calculated by the lattice-strain method of Blundy and Wood 1994, 2003) from eight igneous units are plotted against U/Pr of the zircons, measured by ArF ELAICPMS. As discussed in the text, these ratios must have nearly identical temperature sensitivity of their zircon/melt partition coefficients. Note that the slopes of the arrays do not differ significantly from 1.0 in these eight examples. Standard error of the slope and intercept are $\pm 1 \sigma$. After considering the presence of non-negligible (but unquanti-

procedure of Ballard et al. 2002, using whole-rock compositions), except South Sister and Mt St Helens Yn tephra, which we calculated using glass analyses reported by the respective authors (Electronic Supplementary Material 4). All data arrays in Fig. 10 have regression slopes significantly $<1$. As indicated by the inset vector-decompositions of the data trends, we interpret these regression trends as signifying magma oxidation during crystallisation of the analysed zircon suites. The Devil's Hills rhyolitic lava domes in fiable) analytical uncertainty in these datasets, it is apparent from the slopes and $R^{2}$ values that there is no resolvable component of the variance in $\mathrm{Ce}^{4+} / \mathrm{Ce}^{3+}$ within each array that is attributable to variation of magmatic oxidation state. Data sources: Koksai, Erdenet, Nurkazghan, and Bozshakol porphyry copper deposits: Shen et al. (2015); Shiyaogou porphyry molybdenum deposit: Han et al. (2013); El Abra porphyry copper igneous complex: Ballard et al. (2002); Tampakan volcanic complex: Electronic Supplementary Material 3

the South Sister volcanic complex and the Mt St Helens Yn tephra are the only suites in Fig. 10 for which Fe-Ti oxide data are available for an independent test of redox trend. The negative slopes of the Mt St Helens Yn tephra and South Sister Fe-Ti oxide array in Fig. 1 corroborate the zircon-based $\mathrm{U} / \mathrm{Pr}$ versus $\mathrm{Ce}^{4+} / \mathrm{Ce}^{3+}$ trends in Fig. 10 that indicates melt oxidation during cooling and crystallisation.

Prouteau and Scaillet (2003), Rohrlach and Loucks (2005), Loucks (2014) and Lu et al (2015), among others, 

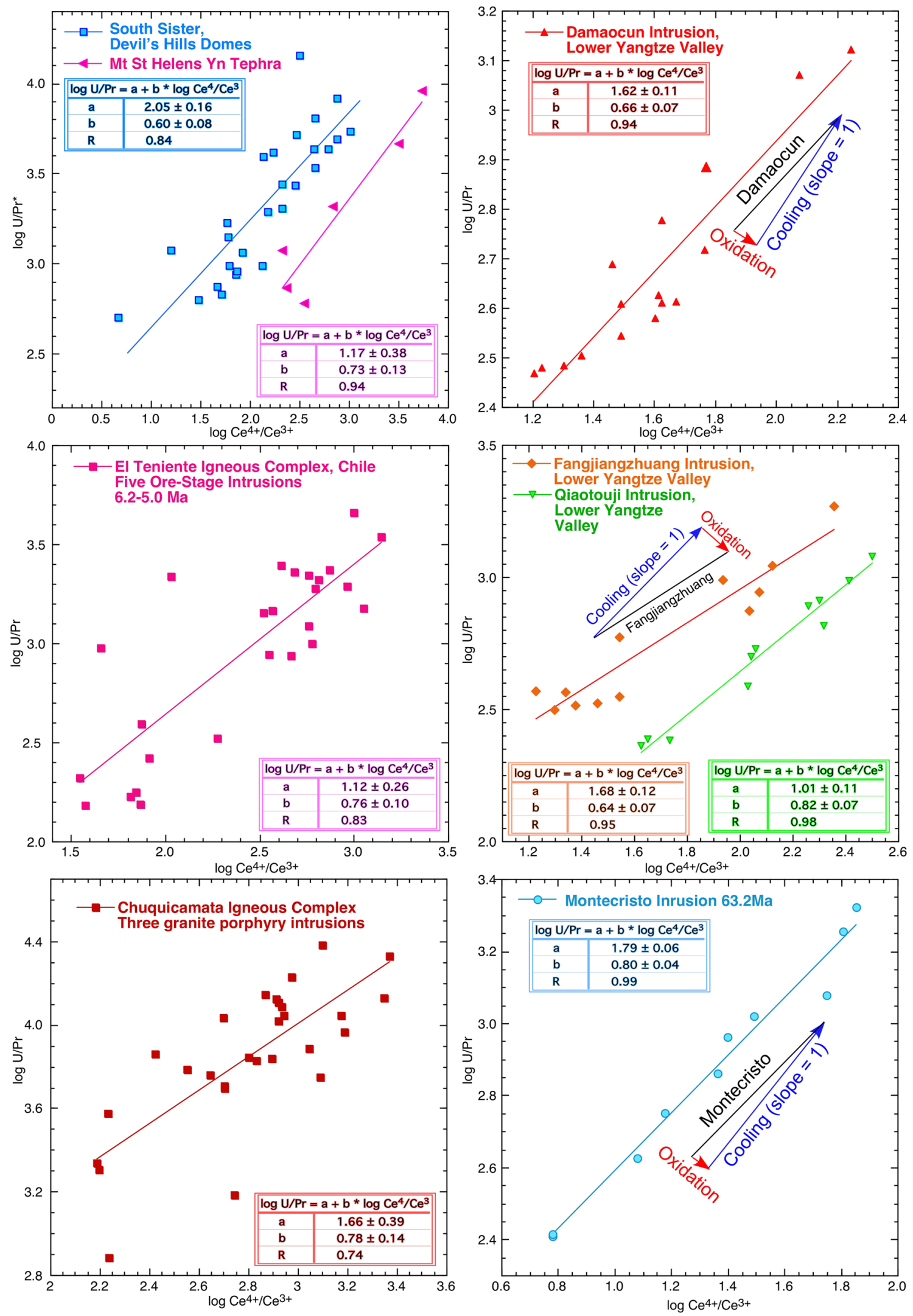
4Fig. 10 Slopes of zircon composition arrays test whether the melt was undergoing reduction or oxidation as the zircon suite crystallised. Zircon $\mathrm{Ce}^{4+} / \mathrm{Ce}^{3+}$ values reported by authors of the source publications (evaluated by the lattice-strain method of Blundy and Wood 1994; Ballard et al. 2002) are plotted against the U/Pr ratios in those zircons, except for South Sister and Mt St Helens suites, for which we calculated zircon $\mathrm{Ce}^{4+} / \mathrm{Ce}^{3+}$ by the same procedure. All arrays have regression slopes $<1$, which implies oxidation of the melt during zircon crystallisation, as indicated in three panels on the right, in which the data trends are decomposed into vector components representing cooling (slope +1.0$)$ and oxidation (slope -1.0$)$. Standard error of the slope and intercept are $\pm 1 \sigma$. Similar vector diagrams apply to panels on the left. South Sister data are from Stelten and Cooper (2012); Mt St Helens data from Claiborne (2011) and Claiborne et al. (2018); El Teniente porphyry copper igneous complex (Chile) data from Muñoz et al. (2012); Lower Yangtze Valley data from Wang et al. (2013); Chuquicamata porphyry copper complex and Montecristo (Chile) data are from Ballard et al. (2002)

demonstrate that adakitic magmas are exceptionally hydrous, commonly with 8-14 wt $\% \mathrm{H}_{2} \mathrm{O}$ dissolved in the silicate melt over most of the course of high-pressure magmatic differentiation. As silicate melts cannot dissolve that much $\mathrm{H}_{2} \mathrm{O}$ at upper-crustal pressures, it is implied that fluid exsolved during ascent of andesitic and dacitic melts to subvolcanic magma chambers, with crystallisation at fluid-saturated conditions upon epizonal emplacement. Oxidation of iron and other redox couples in the melt accompanies dehydration of the melt (Czamanske and Wones 1973; Candela 1986; Gaillard et al. 2002; Rowe et al. 2006). Figure 1 shows that the adakitic suites (Pinatubo, Daisen, Fish Canyon Tuff, and Mt St Helens Yn tephra) have systematically higher $\mathrm{fO}_{2}$ and negative $\mathrm{T}-\mathrm{fO}_{2}$ slopes in the dacitic to rhyolitic composition range. We suggest that exsolution of hydrothermal fluid during magma ascent and epizonal crystallisation is accompanied by partitioning of oxidised sulphur from melt into hydrothermal fluid according to the heterogeneous reaction:

melt melt melt fluid

$\mathrm{SO}_{3}+2 \mathrm{FeO} \rightarrow \mathrm{Fe}_{2} \mathrm{O}_{3}+\mathrm{SO}_{2}$,

wherein exsolution of one mole of $\mathrm{S}^{6+}$ in the melt as $\mathrm{S}^{4+}$ in the fluid is accompanied by oxidation of two moles of $\mathrm{Fe}^{2+}$ in the melt. The effect on $\mathrm{Fe}^{3+} / \mathrm{Fe}^{2+}$ ratio in the residual melt would be greatest in oxidised, Fe-poor felsic melts in which the S:Fe ratio is relatively large at the onset of fluid saturation. Scaillet et al. (1998) demonstrate experimentally that oxidised sulphur is much more volatile as $\mathrm{SO}_{2}$ than as $\mathrm{SO}_{3}$, and that at $\log \mathrm{fO}_{2}>\mathrm{NNO}+1.3$, the fluid/melt partition coefficient of sulphur is $\geq 1000$ in dacitic and more silicic magmas, so this provides a plausible explanation of the negative $\mathrm{T}-\mathrm{fO}_{2}$ slopes at high $\mathrm{fO}_{2}$ in Fig. 1 and slopes $<1$ in Fig. 10. Experiments by Scaillet et al. (1998) indicate that the fluid/melt partition coefficient of sulphur is about 300 times smaller at $\log \mathrm{fO}_{2} \leq \mathrm{NNO}+0.5$, in the stability field of $\mathrm{S}^{2-}$ predominance in the melt. Therefore, gravitational segregation of buoyant hydrothermal fluid as it exsolves should induce some oxidation of the $\mathrm{Ce}^{4+} / \mathrm{Ce}^{3+}$ and $\mathrm{U}^{5+} / \mathrm{U}^{4+}$ and $\mathrm{Fe}^{3+} / \mathrm{Fe}^{2+}$ redox couples in the residual silicate melt and in zircons that grow during decompression and loss of $\mathrm{SO}_{3}$ to exsolving fluid.

Baker and Rutherford (1996) find in experiments at controlled $\mathrm{fO}_{2}$ that change of melt structure with variation of dissolved $\mathrm{H}_{2} \mathrm{O}$ content of metaluminous rhyolite has no effect on the $\mathrm{Fe}^{3+} / \mathrm{Fe}^{2+}$ ratio in the melt at temperatures below $850{ }^{\circ} \mathrm{C}$. However, at magmatic temperatures molecular $\mathrm{H}_{2} \mathrm{O}$ in the melt and in exsolved fluid partially dissociates according to the reaction $\mathrm{H}_{2} \mathrm{O} \rightarrow \mathrm{H}_{2}+1 / 2 \mathrm{O}_{2}$, and loss of $\mathrm{H}_{2}$ to segregating fluid oxidises iron in the residual melt by the reaction $2 \mathrm{FeO}+\mathrm{H}_{2} \mathrm{O} \rightarrow \mathrm{Fe}_{2} \mathrm{O}_{3}+\mathrm{H}_{2}$. As pointed out by Carmichael (1991), in relatively $\mathrm{H}_{2} \mathrm{O}$-poor silicic melts, such as the Toba Tuffs (Chesner and Luhr 2010) and Bishop Tuff (Wallace et al. 1999; Anderson et al. 2000; Roberge et al. 2013) and Yellowstone rhyolites (Almeev et al. 2012; Befus and Gardner 2016), most of the dissolved $\mathrm{H}_{2} \mathrm{O}$ occurs as hydroxyl. Therefore, the $\mathrm{H}_{2} \mathrm{O}$ molecular dissociation reaction does not proceed to as significant a degree as in extremely hydrous magmas.

$\mathrm{H}_{2}$ transfer from silicate melt to exsolving hydrothermal fluid and gravitational segregation of buoyant bubbles from the conjugate melt (forming a fluid cap at the top of the magma column) may provide a supplementary mechanism for inducing the oxidising-cooling trend revealed by the zircon data in Fig. 10 and by the $\mathrm{Fe}-\mathrm{Ti}$-oxide $\mathrm{T}-\mathrm{fO}_{2}$ trends (Fig. 1) of the low-temperature $\left(<800^{\circ} \mathrm{C}\right)$ dacitic/rhyolitic segments of the Pinatubo and St Helens Yn arrays and similar cooling-oxidising trends of other adakitic suites (e.g., Daisen and Fish Canyon). Czamanske and Wones (1973) attribute to segregation of exsolving magmatic hydrothermal fluid and $\mathrm{H}_{2}$ loss from the melt an oxidising-cooling trend during crystallisation of the Finnmarka granitoid complex, Norway. Cornejo and Mahood (1997) attribute to $\mathrm{H}_{2}$ loss the oxidising-cooling $\mathrm{T}-\mathrm{fO}_{2}$ trend in the adakitic La Gloria pluton of Miocene age in central Chile.

Bell and Simon (2011) have identified an additional mechanism for increasing the $\mathrm{Fe}^{3+} / \mathrm{Fe}^{2+}$ ratio in the residual melt as hydrothermal fluid exsolves and physically segregates. Their experiments and thermodynamic data and modelling studies show that over a large range of $\mathrm{fO}_{2}$ relevant to natural magmas, $\mathrm{Fe}^{2+}$ partitions into a chloride-bearing magmatic hydrothermal fluid much more strongly than $\mathrm{Fe}^{3+}$, with the result that fractional segregation of the brine raises the oxidation state of the residual melt. The effect is especially pronounced during exsolution of a relatively large mass of brine from relatively Fe-poor felsic melts.

\section{Suites showing reduction during cooling}

In contrast to the differentiation trends of wet magmas that have slopes $<1$ in Fig. 10 and negative slopes in Fig. 1, we 
Fig. 11 Slopes of zircon composition arrays test whether the melt was undergoing reduction or oxidation as the zircon suite crystallised. The least-squares regression in each panel has a slope $>1.0$, which is decomposed into vector components representing cooling (slope +1 ) and decrease in oxidation state of the melt (slope -1 ). Standard error of the slope and intercept are $\pm 1 \sigma$. In each panel the data trend shows that the redox state of the melt decreased as zircon crystallised from cooling melt. The trends of these zircon arrays corroborate the $\mathrm{Fe}-$ Ti-oxide $\mathrm{T}-\mathrm{fO}_{2}$ trends for these volcanic suites in Fig. 1. a Bishop Tuff zircon crystal rims analysed by Smythe and Brenan (2016, sample BTZ) and by Reid et al. (2011; other sample numbers). The label following the comma is the eruptive stratigraphic unit from which the sample was collected (nomenclature of Hildreth and Wilson 2007). Calculation of zircon $\mathrm{Ce}^{4+} / \mathrm{Ce}^{3+}$ utilises analyses of glass inclusions in Bishop Tuff phenocrysts by Wallace et al. (1999), Anderson et al. (2000), and Roberge et al. (2013). b Zircon crystal-rim compositions in eruptive Unit B of the Yellowstone caldera-forming Lava Creek Tuff supereruption (0.62 Ma), as reported by Wotzlaw et al. (2015) are combined with Lava Creek Tuff Unit B pumice composition as reported by Christiansen (2001). c Toba Tuff zircons and host glass analyses from two pumice samples reported by Gaither (2011)

show in Fig. $11 \log \mathrm{U} / \mathrm{Pr}$ versus $\log \mathrm{Ce}^{4+} / \mathrm{Ce}^{3+}$ trends for zircons in $\mathrm{H}_{2} \mathrm{O}$-poor, fayalite- and pyroxene-phyric, high-silica rhyolites that have positive slopes of the $\mathrm{T}-\mathrm{fO}_{2}$ trends in Fig. 1. The data and procedures for evaluating zircon $\mathrm{Ce}^{4+} /$ $\mathrm{Ce}^{3+}$ in the suites plotted in Fig. 11 are shown in Electronic Supplementary Material 4. Those trends having positive slopes are a subject of dispute, as described in the introduction of this paper. In Fig. 1, the T-fO $\mathrm{O}_{2}$ trend of the Yellowstone Lake Creek fayalite rhyolite and Toba Tuff pyroxene dacite and Toba Tuff high-silica fayalite rhyolite show positive $\mathrm{T}-\mathrm{fO}_{2}$ slopes like the Bishop Tuff pyroxene rhyolite. The zircon composition trends in all three panels of Fig. 11 have slopes substantially $>1$, which corroborate the cooling-reducing trend from $\mathrm{Fe}-\mathrm{Ti}$ oxides for those three suites shown in Fig. 1.

In each of these volcanic suites in Fig. 11, and in the Tampakan and South Sister and Mt St Helens Yn volcanic suites in Figs. 9 and 10, the data dispersion in each array is similar to the degree of dispersion within $\mathrm{T}-\mathrm{fO}_{2}$ arrays of $\mathrm{Fe}-\mathrm{Ti}$ oxide phenocrysts from the same volcanic suites in Fig. 1. The Bishop Tuff and Yellowstone zircon $\mathrm{Ce}^{4+} / \mathrm{Ce}^{3+}$ values in Fig. 11 were calculated by pairing the average zircon "rim" composition (outer 10-15 $\mu \mathrm{m}$ ) in each pumice sample with glass analyses from the same eruptive unit and sampling area, reported by other analysts, to derive apparent zircon/ melt partition coefficients of REEs, Th, $\mathrm{Zr}$ and $\mathrm{Hf}$, which were then used to estimate $\mathrm{Ce}^{4+} / \mathrm{Ce}^{3+}$ in zircon according to the lattice-strain method of Blundy and Wood $(1994,2003)$ (see Electronic Supplementary Material 4). The assumption that zircon and glass represent equilibrium pairs may not be perfect in every case, because chamber replenishment and magma mixing that immediately preceded the eruptions have been well documented in the Bishop Tuff (Evans and Bachmann 2013), Toba Tuff (Chesner and Luhr 2010), and
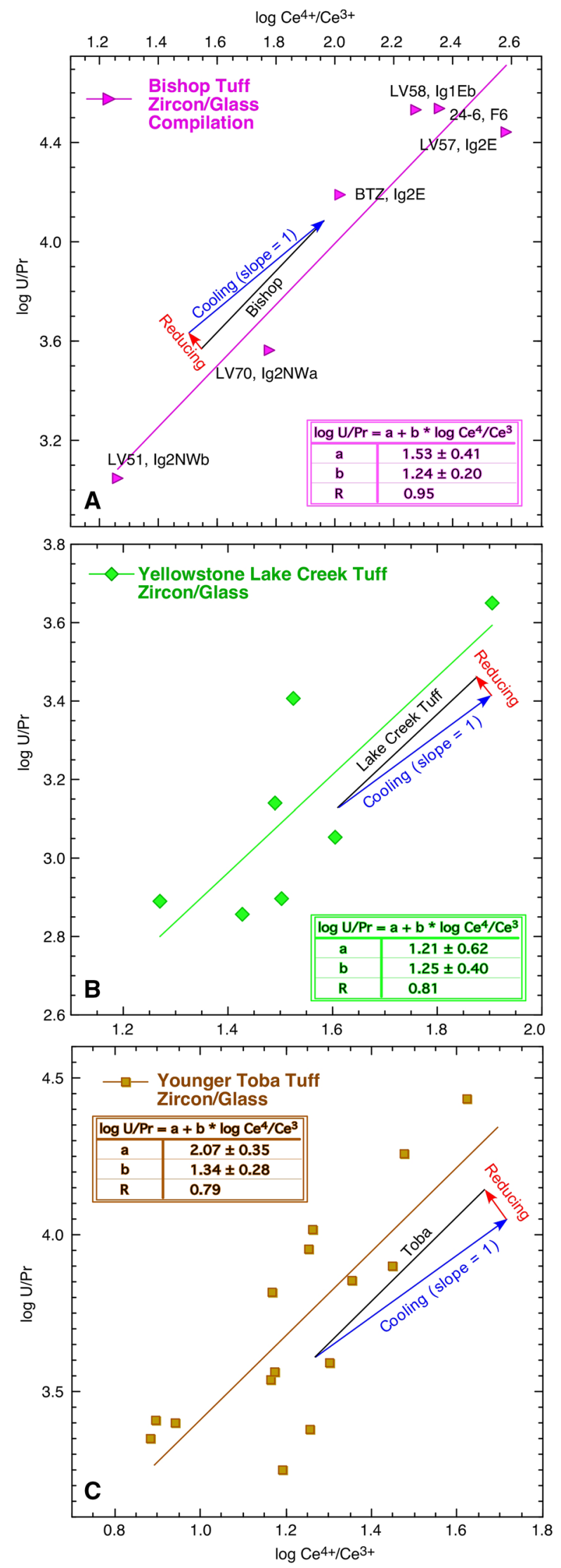
Yellowstone Lake Creek Tuff (Wotzlaw et al. 2015). Such possible heterogeneity in composition of the host glass may contribute analytical dispersion in addition to the compositional heterogeneity within zoned crystals (Fig. 8).

The Bishop Tuff data trend in Fig. 11 implies that successive eruptive units tapped successively deeper levels of a magma chamber that was zoned in oxidation state, with early-erupted, more reduced, cooler magma overlying hotter, less reduced magma that was tapped later in the eruption sequence, corroborating interpretations by Hildreth and Wilson (2007) based on independent evidence from $\mathrm{Fe}-\mathrm{Ti}$ oxides (Fig. 1) and other phenocrysts. Their interpretation that the Bishop Tuff magma chamber had strong vertical gradients in temperature and oxidation state was disputed by Gualda et al. $(2012,2017)$ who claimed, on the basis of Rhyolite-MELTS modelling, that the crystallisation temperature for Bishop Tuff phenocrysts lies within a $10{ }^{\circ} \mathrm{C}$ range from top to bottom of the eruptive sequence.

The cause of the reducing trend during cooling of the Bishop Tuff magma is illuminated by consideration of $\mathrm{Fe}^{3+} /$ $\mathrm{Fe}^{2+}$ ratios in crystals and coexisting melt. Hildreth and Wilson (2007) report that ilmenite phenocrysts are exceedingly sparse in all eruptive units of the Bishop Tuff, and very subordinate to titanomagnetite in modal abundance. Hildreth (1977) carries out wet chemical measurements of $\mathrm{Fe}^{3+} / \mathrm{Fe}^{2+}$ ratios in biotite in several eruptive units of the Bishop Tuff and reports that $40-80 \%$ of the iron in biotite is $\mathrm{Fe}^{3+}$. Multiple lines of evidence summarized by Evans et al. (2016) and references therein show that the pyroxene phenocrysts found in late-erupted units that tapped deeper, hotter parts of the magma chamber are xenocrysts out of chemical equilibrium with all other phenocrysts and glass in the samples. Therefore, the only modally significant Febearing phenocrysts precipitating from the melts represented by erupted pumice are titanomagnetite with $\mathrm{Fe}^{3+} / \mathrm{Fe}^{2+} \approx 1.2$ on average (Hildreth and Wilson 2007) and biotite with a similar $\mathrm{Fe}^{3+} / \mathrm{Fe}^{2+}$ ratio. At $800-850{ }^{\circ} \mathrm{C}$, the Bishop melt was at $\log \mathrm{fO}_{2} \approx \mathrm{NNO}+0.5$ (Fig. 1), so $\mathrm{Fe}^{3+} / \mathrm{Fe}^{2+}$ in the melt was $\sim 0.06$ to 0.07 (Gaillard et al. 2001; Wilke et al. 2002). Precipitation of a phenocryst assemblage having a higher $\mathrm{Fe}^{3+} / \mathrm{Fe}^{2+}$ than the high-silica, Fe-Mg-poor melt can account for the evolution of the melt toward lower $\mathrm{Fe}^{3+} / \mathrm{Fe}^{2}$ with decreasing temperature, as illustrated in Figs. 1 and 11a. Zircon arrays from slowly cooled intrusive suites plotted in Figs. 9 and 10 tend to show less data dispersion.

\section{Implications for formulation of $\mathrm{TiO}_{2}$ activity by the MELTS and Rhyolite-MELTS thermodynamic models}

Rutile solubility experiments in hydrous granitoid melts performed and compiled by Kularatne and Audétat (2014) underpin their thermodynamic model for $\mathrm{TiO}_{2}$ activity in rhyolitic melts. They apply their $\mathrm{TiO}_{2}$ activity model to quartz-hosted glass inclusions in metaluminous and peraluminous rhyolitic volcanic rocks to calculate values of $\mathrm{TiO}_{2}$ activity that are in good agreement with $\mathrm{TiO}_{2}$ activities calculated from $\mathrm{Fe}-\mathrm{Ti}$-oxide phenocrysts in those samples using the method of Ghiorso and Gualda (2013). However, Kularatne and Audétat (2014) report that titania solubilities predicted by MELTS (Ghiorso and Sack 1995) and Rhyolite-MELTS (Gualda et al. 2012) free-energy-minimisation programs are 1.5-2.9 times higher than actually observed $\mathrm{TiO}_{2}$ solubilities in all subaluminous and peraluminous melt compositions investigated in their experimental dataset. Kularatne and Audétat's experiments indicate that rutile solubility is insensitive to alumina saturation index in metaluminous melts having $\mathrm{Al} / \mathrm{Na}+\mathrm{K} \geq 1$, but rutile solubility in peralkaline melts increases strongly with decreasing $\mathrm{Al} /$ $\mathrm{Na}+\mathrm{K}$. The sensitivity of rutile solubility to alumina saturation index in peralkaline melts is consistent with the formation of alkali-titanate complexes as suggested by Dickinson and Hess (1985) and later confirmed by X-ray absorption spectroscopy (e.g., Farges et al. 1996; Farges and Brown 1997).

We infer that the errors in the formulation for $a_{\mathrm{TiO}_{2}}^{\mathrm{melt}}$ by the MELTS and Rhyolite-MELTS thermodynamic models, which underlie the dispute over $\mathrm{T}-\mathrm{fO}_{2}$ trends described in the introduction, may be due to failure to adequately account for the varying structural role of Ti with varying alumina saturation index and hydration state of the melt, with $\mathrm{Ti}$ being largely a "network forming" component (tetrahedrally coordinated with oxygen) in low-pressure peralkaline melts and predominantly a "network-modifying" component (octahedrally coordinated, as in rutile) in peraluminous melts and high-pressure metaluminous melts. If so, then the enthalpy of fusion of rutile must be combined with variable enthalpy of solvation (mixing) of molten $\mathrm{TiO}_{2}$ in aluminosilicate melts of varied $\mathrm{A} / \mathrm{CNK}$ and hydration state (taking $\mathrm{Na}-\mathrm{OH}$ complexing into account; Kohn et al. 1998), to thermodynamically model $a_{\mathrm{TiO}_{2}}^{\text {melt }}$ in thermally and compositionally var-

ied aluminosilicate melts. Our literature survey indicates that rutile saturation at mid- to upper-crustal pressures in nature is largely limited to peraluminous granitoids. We expect that the configurational behavior of $\mathrm{Ti}$ in silicate melts resembles that of $\mathrm{Al}$, which is entirely a tetrahedrally coordinated "network former" in low-pressure peralkaline melts (in which liquidus minerals rich in octahedral $\mathrm{Al}$ are unstable), but 
largely an octahedrally coordinated "network modifier" in peraluminous melts and high-pressure melts that stabilise liquidus minerals rich in octahedrally coordinated Al. By extension of the Burnham (1981) "quasi-crystalline model" for configurational properties of aluminosilicate liquids, MELTS-type thermodynamic models may benefit by transitioning among pressure- and bulk-composition-dependent alternative sets of thermodynamic components of the melt (e.g., using the compositions and fusion enthalpies of CaTS or grossular rather than anorthite, and of jadeite rather than albite) to simplify treatment of configurational entropy and enthalpic mixing properties of aluminosilicate melts over a range of mantle to crustal pressures and varied alumina saturation index. Thermodynamic properties of biotite solid solutions, with particular attention to effective biotite/melt partition coefficients of $\mathrm{Fe}^{3+}$ and $\mathrm{Fe}^{2+}$, may also warrant re-examination in the MELTS and Rhyolite-MELTS programs.

\section{Conclusions}

This work presents new evidence that shows that the $\mathrm{Fe}-\mathrm{Ti}$-oxide oxybarometer calibration by Ghiorso and Evans (2008) retrieves experimentally imposed values of $\mathrm{fO}_{2}$ in laboratory syntheses of $\mathrm{Fe}-\mathrm{Ti}$-oxide pairs to a precision of $\pm 0.2 \log$ unit, over a large experimental temperature range, without systematic bias up to at least log $\mathrm{fO}_{2} \approx \mathrm{NNO}+4.4$. Proceeding from that result, this study addresses a recent dispute (Ghiorso and Gualda 2013; Ghiorso et al 2016; Evans and Bachmann 2013; Evans et al. 2016) regarding the reliability of $\mathrm{T}-f \mathrm{O}_{2}$ trends in the Bishop Tuff magma chamber recorded by titanomagnetite-hemoilmenite phenocryst pairs and trends recovered by Trail et al. (2015) from zircon $\mathrm{Ce}^{4+} / \mathrm{Ce}^{3+}$ ratios and Ti-in-zircon temperatures in the Bishop Tuff. Results from our study show that lattice-strain effects cause $\mathrm{Ce}^{4+} / \mathrm{Ce}^{3+}$ in zircon to increase strongly as zircon crystallises from cooling magma at constant $\mathrm{Ce}^{4+} / \mathrm{Ce}^{3+}$ ratio in the melt. In many natural assemblages described in published literature and interpreted as redox indicators, there is no resolvable change in redox state of the melt over a large range of $\mathrm{Ce}^{4+} / \mathrm{Ce}^{3+}$ variation in zircons. We indicate that those magma chambers have crystallised at constant redox state of the melt in systems closed to oxygen (or hydrogen) exchange with the environs. Exceptionally $\mathrm{H}_{2} \mathrm{O}$-rich arc magmas tend to follow a trend of rising oxidation state of the melt during late stages of fluid-saturated magmatic differentiation at upper-crustal pressures. We suggest that $\mathrm{SO}_{3}$ and/or $\mathrm{H}_{2}$ and/or $\mathrm{Fe}^{2+}$ loss from the melt are responsible. $\mathrm{H}_{2} \mathrm{O}$-poor magmas tend to follow a $\mathrm{T}-\mathrm{fO}_{2}$ trend of decreasing oxidation state of the melt during late stages of magmatic differentiation at upper-crustal pressures, because the precipitating mineral assemblage has higher $\mathrm{Fe}^{3+} / \mathrm{Fe}^{2+}$ than coexisting rhyolitic melt. In conclusion, this study corroborates the validity of the Ghiorso and Evans (2008) Fe-Ti-oxide oxybarometer, and supports the methodology of Ghiorso and Gualda (2013) for evaluating $\mathrm{TiO}_{2}$ activity from quenched $\mathrm{Fe}$-Ti-oxide phenocrysts, and thereby supports use of those $\mathrm{TiO}_{2}$ activity values in application to $\mathrm{Ti}$ in-zircon and Ti-in-quartz geothermometry to address a wide range of fundamental geological problems. We offer suggestions for improving the Rhyolite-MELTS program of Gualda et al. (2012).

Acknowledgements We thank Paul Agnew and Alan Kobussen of Rio Tinto Exploration for financial support and for authorisation to publish research results. Additional financial support was provided by the ARC Centre of Excellence for Core to Crust Fluid Systems Grant CE110001017. MLF acknowledges the support of the Australian Research Council through the Future Fellowship Grant scheme (FT110100241). MLF also acknowledges support from the Australian Research Council through Linkage Project LP120100668. BDR acknowledges WMC Resources Ltd for financial support of his PhD research. RRL thanks the University of Bristol for a Benjamin Meaker Visiting Professorship which afforded an opportunity to clarify his understanding of this material through discussions with Professors Jon Blundy and Chris Hawkesworth. Journal reviews by Jon Blundy and an anonymous reviewer improved the clarity of presentation. This is contribution 1223 from the ARC Centre for Excellence for Core to Crust Fluid Systems (http://www.ccfs.mq.edu.au).

Open Access This article is distributed under the terms of the Creative Commons Attribution 4.0 International License (http://creativeco mmons.org/licenses/by/4.0/), which permits unrestricted use, distribution, and reproduction in any medium, provided you give appropriate credit to the original author(s) and the source, provide a link to the Creative Commons license, and indicate if changes were made.

\section{References}

Almeev RR, Bolte T, Nash BP, Holtz F, Erdmann M, Cathey HE (2012) High-temperature, low- $\mathrm{H}_{2} \mathrm{O}$ silicic magmas of the Yellowstone hotspot: an experimental study of rhyolite from the Bruneau-Jarbidge eruptive center, central Snake River Plain, USA. J Petrol 53(9):1837-1866

Andersen DJ, Lindsley DH, Davidson PM (1993) QUILF: a Pascal program to assess equilibria among $\mathrm{Fe}-\mathrm{Mg}-\mathrm{Mn}-\mathrm{Ti}$ oxides, pyroxenes, olivine and quartz. Comput Geosci 19(9):1333-1350

Anderson AT, Davis AM, Lu F (2000) Evolution of the Bishop Tuff rhyolitic magma based on melt and magnetite inclusions and zoned phenocrysts. J Petrol 41(3):449-473

Baker LL, Rutherford MJ (1996) The effect of dissolved water on the oxidation state of silicic melts. Geochim Cosmochim Acta 60(12):2179-2187

Ballard JR, Palin JM, Campbell IH (2002) Relative oxidation states of magmas inferred from $\mathrm{Ce}(\mathrm{IV}) / \mathrm{Ce}(\mathrm{III})$ in zircon: application to porphyry copper deposits of northern Chile. Contrib Mineral Petrol 144(3):347-364

Befus KS, Gardner JE (2016) Magma storage and evolution of the most recent effusive and explosive eruptions from Yellowstone Caldera. Contrib Mineral Petrol 171:30 
Bell AS, Simon A (2011) Experimental evidence for the alteration of the $\mathrm{Fe}^{3+} / \Sigma \mathrm{Fe}$ of silicate melt caused by the degassing of chlorinebearing aqueous volatiles. Geology 39(5):499-502

Berndt J, Koepke J, Holtz F (2005) An experimental investigation of the influence of water and oxygen fugacity on differentiation of MORB at $200 \mathrm{MPa}$. J Petrol 46(1):135-167

Berry AJ, O'Neill HSTC, Foran GJ (2008) The oxidation state of uranium in mantle melts. Geochim Cosmochim Acta 72(12):A79

Bindeman IN, Valley JW (2002) Oxygen isotope study of the Long Valley magma system, California: isotope thermometry and convection in large silicic magma bodies. Contrib Mineral Petrol 144:185-205

Blatter DL, Sisson TW, Hankins WB (2013) Crystallization of oxidized, moderately hydrous arc basalt at mid- to lower-crustal pressures: implications for andesite genesis. Contrib Mineral Petrol 166:861-886

Blundy J, Wood B (1994) Prediction of crystal-melt partition coefficients from elastic moduli. Nature 372(6505):452-454

Blundy J, Wood B (2003) Mineral-melt partitioning of uranium, thorium and their daughters. Revs Mineral Geochem 52:59-123

Blundy J, Cashman K, Humphreys M (2006) Magma heating by decompression-driven crystallisation beneath andesite volcanoes. Nature 443:76-80

Blundy J, Cashman K, Berlo K (2008) Evolving magma storage conditions beneath Mount St. Helens inferred from chemical variations in melt inclusions from the 18979-1986 and current (2004-2006) eruptions. USGS Prof Pap 1750:755-790

Brice JC (1975) Some thermodynamic aspects of the growth of strained crystals. J Cryst Growth 28:249-253

Burgisser A, Scaillet B (2007) Redox evolution of a degassing magma rising to the surface. Nature 445:194-197

Burnham CW (1981) The nature of multicomponent aluminosilicate melts. Phys Chem Earth 13/14:197-229

Burnham AD, Berry AJ (2012) An experimental study of trace element partitioning between zircon and melt as a function of oxygen fugacity. Geochim Cosmochim Acta 95:196-212

Burnham AD, Berry AJ (2014) The effect of oxygen fugacity, melt composition, temperature and pressure on the oxidation state of cerium in silicate melts. Chem Geol 366:52-60

Burnham AD, Berry AJ (2017) Formation of Hadean granites by melting of igneous crust. Nat Geosci 10:457-461

Candela PA (1986) The evolution of aqueous vapor from silicate melts: effect on oxygen fugacity. Geochim Cosmochim Acta 50:1205-1211

Carmichael ISE (1967) The mineralogy of Thingmuli, a Tertiary volcano in eastern Iceland. Amer Mineral 52:1815-1841

Carmichael ISE (1991) The redox states of basic and silicic magmas: a reflection of their source regions? Contrib Mineral Petrol 106(2):129-141

Carmichael ISE, Ghiorso MS (1986) Oxidation-reduction relations in basic magma: a case for homogeneous equilibria. Earth Planet Sci Lett 78(2-3):200-210

Cathey HE, Nash BP (2004) The Cougar Point Tuff: implications for thermochemical zonation and longevity of high-temperature, large-volume silicic magmas of the Miocene Yellowstone hotspot. J Petrol 45(1):27-58

Chamberlain KJ, Wilson CJN, Wooden JL, Charlier BLA, Ireland TR (2014) New perspectives on the Bishop Tuff from zircon textures, ages, and trace elements. J Pet 55:395-426

Chamberlain KJ, Wilson CJN, Wallace PJ, Millet M-A (2015) Microanalytical perspectives on the Bishop Tuff and its magma chamber. J Petrol 56:605-640

Cherniak DJ, Watson EB (2003) Diffusion in zircon. Rev Mineral Geochem 53:113-143

Chesner CA (1998) Petrogenesis of the toba tuffs. Sumatra Indonesia J Petrol 39:397-438
Chesner CA, Luhr JF (2010) A melt inclusion study of the TobaTuffs, Sumatra, Indonesia. J Volc Geoth Res 197:259-278

Christiansen RL (2001) The Quaternary and Pliocene Yellowstone Plateau volcanic field of Wyoming, Idaho, and Montana. US Geol Surv Prof Pap 729-G:156

Claiborne LL (2011) Understanding upper crustal silicic magmatic systems using the temporal, compositional, and thermal record in zircon. Ph.D. Dissertation, Vanderbilt University, p 385

Claiborne LL, Miller CF, Gualda GAR, Carley TL, Covey AK, Wooden JL, Fleming MA (2018) Zircon as magma monitor: robust, temperature-dependent partition coefficients from glass and zircon surface and rim measurements from natural systems. In: Moser DE, Corfu F, Darling JR, Reddy SM, Tait K (eds) Microstructural geochronology: planetary records down to atom scale. Geophysical Monograph 232, American Geophysical Union/Wiley, Oxford, p 3-33

Cornejo PC, Mahood GA (1997) Seeing past the effects of re-equilibration to reconstruct magmatic gradients in plutons: La Gloria Pluton, central Chilean Andes. Contrib Mineral Petrol 127:159-175

Crowley JL, Schoene B, Bowring SA (2007) U-Pb dating of zircon in the Bishop Tuff at the millennial scale. Geology 35:1123-1126

Czamanske GK, Wones DR (1973) Oxidation during magmatic differentiation, Finnmarka Complex, Oslo area, Norway: Part 2, the mafic silicates. J Petrol 14:349-380

Delano J (2001) Redox history of the Earth's interior since 3900 Ma: implications for prebiotic molecules. Orig Life Evol Biosph 31:311-341

Dickinson JE, Hess PC (1985) Rutile solubility and titanium coordination in silicate melts. Geochim Cosmochim Acta 49:2289-2296

Evans BW, Bachmann O (2013) Implications of equilibrium and disequilibrium among crystal phases in the Bishop Tuff. Am Mineral 98:271-274

Evans BW, Hildreth W, Bachmann O, Scaillet B (2016) In defense of magnetite-ilmenite thermometry in the Bishop Tuff and its implication for gradients in silicic magma reservoirs. Am Mineral 101(2):469-482

Farges F, Brown GE Jr, Rehr JJ (1996) Coordination chemistry of $\mathrm{Ti}(\mathrm{IV})$ in silicate glasses and melts: I. XAFS study of titanium coordination in oxide model compounds. Geochim Cosmochim Acta 60:3023-3038

Farges F, Brown GE Jr (1997) Coordination chemistry of Ti(IV) in silicate glasses and melts: IV. XANES study of synthetic and natural volcanic glasses and tektites at ambient temperature and pressure. Geochim Cosmochim Acta 61:1863-1870

Farges F, Ponader W, Calas G, Brown GE Jr (1992) Structural environments of incompatible elements in silicate glass/melt systems: II. $\mathrm{U}^{\mathrm{IV}}, \mathrm{U}^{\mathrm{V}}$, and $\mathrm{U}^{\mathrm{VI}}$. Geochim Cosmochim Acta 56:4205-4220

Ferry JM, Watson EB (2007) New thermodynamic models and revised calibrations for the Ti-in-zircon and $\mathrm{Zr}$-in-rutile thermometers. Contrib Mineral Petrol 154:429-437

Fonseca ROC, Mallmann G, Sprung P, Sommer JE, Heuser A, Speelmanns IM, Blanchard H (2014) Redox controls on tungsten and uranium crystal/silicate melt partitioning and implications for the U/W and Th/W ratio of the lunar mantle. Earth Planet Sci Lett 404:1-13

Gaillard F, Scaillet B, Pichavant M, Bény J-M (2001) The effect of water and $\mathrm{fO}_{2}$ on ferric-ferrous ratio of silicic melts. Chem Geol 174:255-273

Gaillard F, Scaillet B, Pichavant M (2002) Kinetics of iron oxidationreduction in hydrous silicic melts. Amer Mineral 87:829-837

Gaither TA (2011) Zircon geochemistry and geothermometry of the youngest Toba Tuff. Unpub. MSc. Thesis, Northern Arizona University, p 154

Gardner JE, Carey S, Rutherford MJ, Sigurdsson H (1995) Petrologic diversity in Mount St. Helens dacites during the last 4,000 
years: implications for magma mixing. Contrib Mineral Petrol 119:224-238

Gardner JE, Befus K, Gualda GAR, Ghiorso MS (2014) Experimental constraints on rhyolite-MELTS and the Late Bishop Tuff magma body. Contrib Mineral Petrol 168(2):1-14

Ghiorso MS, Sack RO (1995) Chemical mass transfer in magmatic processes IV. A revised and internally consistent thermodynamic model for the interpolation and extrapolation of liquid-solid equilibria in magmatic systems at elevated temperatures and pressures. Contrib Mineral Petrol 119(2-3):197-212

Ghiorso MS, Evans BW (2008) Thermodynamics of rhombohedral oxide solid solutions and a revision of the Fe-Ti two oxide geothermometer and oxygen-barometer. Am J Sci 308(9):957-1039

Ghiorso MS, Gualda GAR (2013) A method for estimating the activity of titania in magmatic liquids from the compositions of coexisting rhombohedral and cubic iron-titanium oxides. Contrib Mineral Petrol 165:73-81

Ghiorso MS, Gualda GAR, Pamukcu AS, Gardner JE (2016) Apparent temperature-redox trends in the Bishop Tuff: a result of rapid growth of $\mathrm{Fe}-\mathrm{Ti}$ oxides under constant temperature/redox state conditions. Am Geophys Union Fall Mtg, Abs V24C-01

Gualda GAR, Ghiorso MS, Lemons RV, Carley TL (2012) RhyoliteMELTS: a modified calibration of MELTS optimized for silicarich, fluid-bearing magmatic systems. J Pet 53:875-890

Gualda GAR, Ghiorso MS, Hurst AA, Allen MC, Bradshaw RW (2017) Patchy distribution of magma that fed the Bishop Tuff supereruption: evidence from matrix glass major and trace-element compositions. Am Geophys Union Fall Mtg, Abs V11C-0369

Han Y, Zhang S, Pirajno F, Zhou X, Zhao G, Qu W, Liu S, Zhang J, Liang H, Yang K (2013) U-Pb and Re-Os isotopic systematics and zircon $\mathrm{Ce}^{4+} / \mathrm{Ce}^{3+}$ ratios in the Shiyaogou Mo deposit in eastern Qinling, central China: insights into the oxidation state of granitoids and $\mathrm{Mo}(\mathrm{Au})$ mineralization. Ore Geol Revs 55:29-47

Hanchar JM, Watson EB (2003) Zircon saturation thermometry. Revs Mineral Geochem 53:89-112

Hildreth W (1977) The magma chamber of the Bishop Tuff: gradients, temperature, pressure and composition. Ph.D. thesis, University of California, Berkeley, California, p 328

Hildreth W (1983) The compositionally zoned eruption of 1912 in the valley of ten thousand smokes, Katmai National Park, Alaska. J Volc Geoth Res 18:1-56

Hildreth W, Wilson CJN (2007) Compositional zoning of the Bishop Tuff. J Pet 48(5):951-999

Hofmann AE, Baker MB, Eiler JM (2014) Sub-micron-scale traceelement distributions in natural zircons of known provenance: implications for Ti-in-zircon thermometry. Contrib Mineral Petrol 168:1057

Holland T, Blundy J (1994) Non-ideal interactions in calcic amphiboles and their bearing on amphibole-plagioclase thermometry. Contrib Mineral Petrol 116(4):433-447

Huang R, Audétat A (2012) The titanium-in-quartz (TitaniQ) thermobarometer: a critical examination and re-calibration. Geochim Cosmochim Acta 84:75-89

Kohn SC, Smith ME, Dirken PJ, van Eck ERH, Kentgens APM, Dupree $\mathrm{R}$ (1998) Sodium environments in dry and hydrous albite glasses: improved ${ }^{23} \mathrm{Na}$ solid state NMR data and their implications for water dissolution mechanisms. Geochim Cosmochim Acta 62:79-87

Kress VC, Carmichael ISE (1991) The compressibility of silicate liquids containing $\mathrm{Fe}_{2} \mathrm{O}_{3}$ and the effect of composition, temperature, oxygen fugacity and pressure on their redox states. Contrib Mineral Petrol 108:82-92

Kularatne K, Audétat A (2014) Rutile solubility in hydrous rhyolite melts at $750-900{ }^{\circ} \mathrm{C}$ and $2 \mathrm{kbar}$, with application to titanium-inquartz (TitaniQ) thermobarometry. Geochim Cosmochim Acta 125:196-209
Loucks RR (2014) Distinctive composition of copper-ore-forming arc magmas. Austral J Earth Sci 61:5-16

Lu Y-J, Loucks RR, Fiorentini ML, Yang ZM, Hou Z-Q (2015) Fluid flux melting generated postcollisional high $\mathrm{Sr} / \mathrm{Y}$ copper-oreforming water-rich magmas in Tibet. Geology 43:583-586

Luo Y, Ayers JC (2009) Experimental measurements of zircon/melt trace-element partition coefficients. Geochim Cosmochim Acta 73:3656-3679

Muñoz M, Charrier R, Fanning CM, Maksaev V, Deckart K (2012) Zircon trace element and $\mathrm{O}-\mathrm{Hf}$ isotope analyses of mineralized intrusions from El Teniente ore deposit, Chilean Andes: constraints on the source and magmatic evolution of porphyry $\mathrm{Cu}-\mathrm{Mo}$ related magmas. J Pet 53(6):1091-1122

O'Neill HSC (1987) Quartz-fayalite-iron and quartz-fayalite-magnetite equilibria and the free energy of formation of fayalite $\left(\mathrm{Fe}_{2} \mathrm{SiO}_{4}\right)$ and magnetite $\left(\mathrm{Fe}_{3} \mathrm{O}_{4}\right)$. Am Mineral 72:67-75

Perfit MR, Fornari DJ (1983a) Geochemical studies of abyssal lavas recovered by DSRV Alvin from the eastern Galapagos Rift, Inca Transform, and Ecuador Rift 3. Trace element abundances and petrogenesis. J Geophys Res 88:10551-10572

Perfit MR, Fornari DJ (1983b) Geochemical studies of abyssal lavas recovered by DSRV alvin from eastern galapagos rift, inca transform, and ecuador rift 2 . phase chemistry and crystallisation history. J Geophys Res 88:10530-10550

Pichavant M, Montel J-M, Richard LR (1992) Apatite solubility in peraluminous liquids: experimental data and an extension of the Harrison-Watson model. Geochim Cosmochim Acta 56(10):3855-3861

Pichavant M, Martel C, Bourdier JL, Scaillet B (2002) Physical conditions, structure, and dynamics of a zoned magma chamber: mount Peleé (Martinique, Lesser Antilles Arc). J Geophys Res 107(B5):2093

Pownceby MI, O’Neill HSC (1994) Thermodynamic data from redox reactions at high temperatures. IV. Calibration of the $\mathrm{Re}-\mathrm{ReO}_{2}$ oxygen buffer from EMF and $\mathrm{NiO}+\mathrm{Ni}-\mathrm{Pd}$ redox sensor measurements. Contrib Mineral Petrol 118(2):130-137

Preece SJ, McGimsey RG, Westgate JA, Pearce NJG, Hart WK, Perkins WT (2014) Chemical complexity and source of the White River Ash, Alaska and Yukon. Geosphere 10:1020-1042

Prouteau G, Scaillet B (2003) Experimental constraints on the origin of the 1991 Pinatubo dacite. Jour Petrol 44(12):2203-2241

Reid MR, Vazquez JA, Schmitt AK (2011) Zircon-scale insights into the history of a supervolcano, Bishop Tuff, Long Valley, California, with implications for the Ti-in-zircon geothermometer. Contrib Mineral Petrol 161:293-311

Righter K, Chesley JT, Geist D, Ruiz J (1998) Behavior of Re during magma fractionation: an example from Volcán Alcedo, Galápagos. J Pet 39:785-795

Roberge J, Wallace PJ, Kent AJR (2013) Magmatic processes in the Bishop Tuff rhyolitic magma based on trace elements in melt inclusions and pumice matrix glass. Contrib Mineral Petrol 165:237-257

Rohrlach BD (2002), Tectonic evolution, petrochemistry, geochronology and palaeohydrology of the Tampakan porphyry and high sulphidation epithermal $\mathrm{Cu}-\mathrm{Au}$ deposit Mindanao, Philippines. Unpub PhD thesis, Australian National University, Canberra, Australia, p 499

Rohrlach BD, Loucks RR (2005) Multi-million-year cyclic ramp-up of volatiles in a lower-crustal magma reservoir trapped below the Tampakan copper-gold deposit by Mio-Pliocene crustal compression in the southern Philippines. In: Porter TM (ed) Super porphyry copper $\&$ gold deposits-a global perspective, vol 2. PCG, Adelaide, pp 369-407

Rowe MC, Nielsen RL, Kent AJR (2006) Anomalously high Fe contents in rehomogenized olivine-hosted melt inclusions from oxidised magmas. Am Mineral 91:82-91 
Rubatto D, Hermann J (2007) Experimental zircon/melt and zircon/ garnet trace element partitioning and implications for the geochronology of crustal rocks. Chem Geol 241:38-61

Scaillet B, Evans BW (1999) The 15 June 1991 eruption of Mount Pinatubo. I. Phase equilibria and pre-eruption $\mathrm{P}-\mathrm{T}-\mathrm{fO}_{2}-f \mathrm{H}_{2} \mathrm{O}$ conditions of the dacite magma. J Pet 40:381-411

Scaillet B, Clemente B, Evans B, Pichavant M (1998) Redox control of sulfur degassing in silicic magmas. J Geophys Res 103:23937-23949

Schreiber HD (1987) An electrochemical series of redox couples in silicate melts: a review and applications to geochemistry. J Geophys Res 92:9225-9232

Schreiber HD, Andrews SM (1980) The redox states of uranium in synthetic basaltic magmas. [Abstract]. In: Lunar and planetary science conference proceedings XI, pp 1000-1002

Schreiber HD, Merkel RC Jr, Schreiber VL, Balazs GB (1987) Mutual interactions of redox couples via electron exchange in silicate melts: models for geochemical melt systems. J Geophys Res 92:9233-9245

Shannon RD (1976) Revised effective ionic radii and systematic studies of interatomic distances in halides and chalcogenides. Acta Crystall A32:751-767

Shen P, Hattori K, Pan H, Jackson S, Seitmuratova E (2015) Oxidation condition and metal fertility of granitic magmas: zircon traceelement data from porphyry $\mathrm{Cu}$ deposits in the Central Asian Orogenic Belt. Econ Geol 110(7):1861-1878

Smythe DJ, Brenan JM (2015) Cerium oxidation state in silicate melts: combined $f \mathrm{O}_{2}$, temperature and compositional effects. Geochim Cosmochim Acta 170:173-187

Smythe DJ, Brenan JM (2016) Magmatic oxygen fugacity estimated using zircon-melt partitioning of cerium. Earth Planet Sci Lett 453:260-266

Stelten ME, Cooper KM (2012) Constraints on the nature of the subvolcanic reservoir at South Sister volcano, Oregon, from U-series dating combined with sub-crystal trace-element analysis of plagioclase and zircon. Earth Planet Sci Lett 313-314:1-11

Tailby ND, Walker AM, Berry AJ, Hermann J, Evans KA, Mavrogenes JA, O'Neill HSC, Rodina IS, Soldatov AV, Rubatto D, Sutton SR (2011) Ti site occupancy in zircon. Geochim Cosmochim Acta 75:905-921

Thomas JB, Watson BE (2012) Application of the Ti-in-quartz thermobarometer to rutile-free systems. Reply to: a comment on: "TitaniQ under pressure: the effect of pressure and temperature on the solubility of Ti in quartz" by Thomas et al. Contrib Mineral Petrol 164:369-374

Trail D, Watson EB, Tailby ND (2011) The oxidation state of Hadean magmas and implications for early Earth's atmosphere. Nature 480(7375):79-82

Trail D, Watson EB, Tailby ND (2012) Ce and Eu anomalies in zircon as proxies for the oxidation state of magmas. Geochim Cosmochim Acta 97(1):70-87

Trail D, Tailby ND, Lanzirotti A, Newville M, Thomas JB, Watson EB (2015) Redox evolution of silicic magmas: insights from XANES measurements of Ce valence in Bishop Tuff zircons. Chem Geol 402:77-88

Venezky DY, Rutherford MJ (1997) Pre-eruption conditions and timing of dacite-andesite mixing in the $2.2 \mathrm{ka}$ eruption of Mount Rainier. J Geophys Res 102(B9):20,068-020,086

Wallace PJ, Anderson AT, Davis AM (1999) Gradients in $\mathrm{H}_{2} \mathrm{O}, \mathrm{CO}_{2}$, and exsolved gas in a large-volume silicic magma system: interpreting the record preserved in melt inclusions from the Bishop Tuff. J Geophys Res, 140(B9):20,097-20,122

Wang F, Liu S-A, Li S, He Y (2013) Contrasting zircon Hf-O isotopes and trace elements between ore-bearing and ore-barren adakitic rocks in central-eastern China: implications for genetic relation to $\mathrm{Cu}-\mathrm{Au}$ mineralization. Lithos 156-159:97-111

Wark DA, Watson EB (2006) TitaniQ: a titanium-in-quartz geothermometer. Contrib Mineral Petrol 152:743-754

Watson EB, Harrison TM (1983) Zircon saturation revisited: temperature and composition effects in a variety of crustal magma types. Earth Planet Sci Lett 64:295-304

Wilke M, Behrens H, Burkhard DJM, Rossano S (2002) The oxidation state of iron in silicic melt at $500 \mathrm{MPa}$ water pressure. Chem Geol 189:55-67

Wotzlaw J-F, Bindeman IN, Stern RA, D'Abzac F-X, Schaltegger U (2015) Rapid heterogeneous assembly of multiple magma reservoirs prior to Yellowstone supereruptions. Nat Sci Rep 5:14026

Yakymchuk C, Clark C, White RW (2017) Phase relations, reaction sequences and petrochronology. Revs Mineral Geochem $83: 13-53$

Publishers Note Springer Nature remains neutral with regard tojurisdictional claims in published maps and institutional affiliations.

\section{Affiliations}

\section{Robert R. Loucks ${ }^{1,2}$ (1) - Marco L. Fiorentini ${ }^{1,2} \cdot$ Bruce D. Rohrlach ${ }^{3,4}$}

\section{Robert R. Loucks}

Robert.Loucks@uwa.edu.au

Marco L. Fiorentini

Marco.Fiorentini@usa.edu.au

Bruce D. Rohrlach

brohrlach@sunstonemetals.com.au

1 Centre for Exploration Targeting, School of Earth Sciences, University of Western Australia, 35 Stirling Highway, Crawley, WA 6009, Australia
2 ARC Centre of Excellence in Core to Crust Fluid Systems, University of Western Australia, 35 Stirling Highway, Crawley, WA 6009, Australia

3 Research School of Earth Sciences, Australian National University, Mills Road, Acton, ACT 2601, Australia

4 Present Address: Sunstone Metals Ltd., Gardner Close, P.O. Box 1565, Milton, QLD 4064, Australia 